\title{
Research Articles \\ First Steps: Synthetic Ammonia in the United States
}

Citation: Travis A. S. (2021) First Steps: Synthetic Ammonia in the United States. Substantia 5(2): 55-77. doi: 10.36253/Substantia-1181

Received: Jan 06, 2021

Revised: Apr 27, 2021

Just Accepted Online: Apr 28, 2021

Published: Sep 10, 2021

Copyright: (C) 2021 Travis A. S. This is an open access, peer-reviewed article published by Firenze University Press (http://www.fupress.com/substantia) and distributed under the terms of the Creative Commons Attribution License, which permits unrestricted use, distribution, and reproduction in any medium, provided the original author and source are credited.

Data Availability Statement: All relevant data are within the paper and its Supporting Information files.

Competing Interests: The Author(s) declare(s) no conflict of interest.

\author{
Anthony S. Travis \\ Sidney M. Edelstein Center for the History and Philosophy of Science, Technology and \\ Medicine, Safra Campus, The Hebrew University of Jerusalem, Jerusalem, Israel \\ E-mail: tony.travis282@gmail.com
}

\begin{abstract}
The synthetic ammonia industry, originally based on Fritz Haber's 1909 invention of a catalytic high-pressure method as scaled up by Carl Bosch at BASF, grew globally in the years following World War I, based on the processes of Brunner, Mond \& Co. (Britain), Luigi Casale (Italy), Georges Claude (France), and Giacomo Fauser (Italy). The ammonia was mainly converted into ammonium sulphate fertilizer. There was less impetus in the United States for taking up these developments, because America relied on ammonia from its by-product coking ovens and coal gas works, sodium nitrate (Chilean nitrate) from South America, and calcium cyanamide as manufactured by the American Cyanamid Company. Even when a synthetic ammonia industry started up in the United States, it was on a smaller scale than in Europe. However there emerged just before the Wall Street Crash two major producers of synthetic ammonia, Allied Chemical and Du Pont. This article presents a historical reconstruction of the early synthetic ammonia industry in the United States focusing on the 1920s, paying particular attention to Du Pont's success, which relied on the ammonia process of Casale. Standard accounts suggest that Du Pont acquired Casale technology as the result of a straightforward business acquisition. However, the situation, as shown here, was far more complex. Du Pont had to engage in aggressive litigation in order to acquire rights to the Casale process in 1927.
\end{abstract}

Keywords: synthetic ammonia, Casale process, Niagara Ammonia Company, Allied Chemical, Du Pont.

\section{INTRODUCTION}

The 1920s were the take off years for science-based chemical industry in the United States. This is nowhere better illustrated than in the realm of coal-based synthetic organic chemistry, in which American firms drew on German technology to master and even excel in the production of colorants and, later, novel products, such as pharmaceuticals, derived from the dye intermediates. ${ }^{1}$ The need to catch up with Germany, and to invent new products for new needs, such as the automobile industry, stimulated unprecedented research and development. The growth and diversification of the US chemical industry was tremendous, and included development of novel polymers, and expansion at firms engaged in electrochemical technologies. Some 
of the most significant developments drew on catalyzed, high-pressure industrial chemistry, following introduction of the Haber-Bosch synthetic ammonia process by BASF in 1913. ${ }^{2}$ In this area of chemical technology, however, the United States was a late starter. Relative to the synthetic dye industry, the parallels, particularly with imitation of German dye technology, are more difficult to discern. This article will explore the several reasons, as well as the early development of the US synthetic ammonia industry.

The extraordinary success of the Haber-Bosch synthetic ammonia process in contributing to Germany's industrial effort in the production of munitions during World War I was widely acknowledged. ${ }^{3}$ After the cessation of hostilities, BASF was not prepared to license the process, preferring instead to use it as a bargaining tool in attempts to gain access to various international tie-ups and also to control the global market in nitrogen fertilizer. This pretention to world leadership, however, spawned imitators, and rivalry.

Here we recount two related but distinct storiesinsofar as they concern similar technologies and their transfers across the Atlantic from Europe-in the development of the large-scale American synthetic ammonia industry. One concerns the Allied Chemical \& Dye Corporation, whose process originated with one of its predecessor firms, and was similar in operating conditions to the Haber-Bosch process. The other describes the Du Pont corporation's entry into synthetic ammonia, based on the acquisition of the processes of Georges Claude (France) and Luigi Casale (Italy) that were worked at around four times the pressure of the Haber-Bosch process. It was the Casale process that enabled Du Pont to become an American technology and market leader in high-pressure chemistry. For this reason I focus mainly on $\mathrm{Du}$ Pont's entry into what was also a completely new venture, based on a novel technology that relied on sophisticated engineering expertise, and that was decidedly removed from synthetic dyes. The background involves the transfer in 1927 of Casale technology from an ambitious but struggling start-up to Du Pont, which planned a major scale up of ammonia manufacture, mainly for the fertilizer market, particularly of ammonium sulphate.

At the outset, it should be pointed out that massive transatlantic technology transfer from Europe, whether of dyes or of high-pressure chemistry, by whatever means, was part of a pattern that impacted on the entire American chemical industry during the 1920s. Much of this encounter has been well analysed, including the mergers and acquisitions, and the partnerships with Europan firms, that led to the rapid growth of major corporations. Shortages of vital chemicals as a result of the cutting off of imports from Germany during World War I provided the impetus for diversification, and for the foundation of start-ups that mastered many features of synthetic organic chemistry, often using information gleaned from sequestered German patents. In some cases, the war enabled the survival and expansion of struggling firms. In others, firms denied access to intermediates made in Europe drew on processes that under peacetime conditions were not economically viable. What is absent in many cases from the historical record are accounts of the complexities of how this industrial transformation was achieved at a more detailed level. This account is an attempt to compensate for the lacunae in one specific sector, though it serves as an outstanding indicator of what was achieved overall by 1930. Its contemporary relevance to the historian resides in the oft neglected focus on the technologies involved; they are often overlooked in accounts that are more focused on business history.

As is frequently the case in the pursuit of industrial history, archival sources are limited, often long ago lost in fires and explosions or discarded following mergers and acquisitions. Fortunately there is adequate material to guide us at the Hagley Museum and Library, in Wilmington, Delaware, in examining an important part of the early history of synthetic ammonia in America. We are aided by the few articles on developments in the United States published between 1930 and the early 1950s, particularly since records of technical progress at Du Pont are mainly absent. ${ }^{4}$ While the fragments of history may not make a whole, they can certainly aid our understanding of how the synthetic ammonia industry evolved in America.

Among the handful of novel, successful ammonia processes developed in Europe around 1920, the most widely adopted, and successful, was that of the Italian chemist and entrepreneur Luigi Casale, who requires a brief introduction.

\section{LUIGI CASALE}

Luigi Casale (1882-1927) studied chemistry at the Royal Polytechnic of Turin (Reale Politecnico di Torino), where he graduated in 1908. His teacher was Arturo Miolati (1869-1956). During 1909-1912, Casale worked under Michel Fileti at the Turin Institute of Chemistry, where he received his postgraduate degree in $1910 .^{5}$ Publicity surrounding the successful outcome of Fritz Haber's work at Karlsruhe on a high-pressure synthetic ammonia method no doubt stimulated Casale's interest 
in physical chemistry and gas reactions at high pressures. During 1912-1913, Casale undertook research in physical chemistry under Walther Nernst, in Berlin, and kept in touch with the latest developments in the thermodynamics of gas reactions, as well as their commercial utility. After returning to Italy, Casale undertook research in organic chemistry, as assistant of Miolati, during 1913-1915, while retaining an interest in synthetic ammonia.

During World War I, after studies on war gases, Casale worked at industrial concerns, including the electrochemical firm IDROS (Società IDROS; it derived its name from idrogeno and ossigeno), founded on 19 February 1916, to supply hydrogen to the Italian navy for dirigible and other aerial balloons, and oxygen for oxyacetylene welding. IDROS was located in Terni, Umbria, close to Italy's main steelworks company. Hydroelectricity provided an inexpensive source of power for IDROS. Around 1917, while at IDROS, Casale began to study the synthesis of ammonia from its elements. By 1920, assisted by the American physicist and inventor René Leprestre (1876-1941), Casale had invented a high-pressure ammonia process. The main inventive concepts included application of far higher pressures (at up to 850 atmospheres) than used in the Haber-Bosch process (around 200 atmospheres) and a converter made of ordinary steel that survived the huge stresses. As with the HaberBosch process, unreacted gases were recirculated to the converter through a closed loop. The yield of ammonia was around fifteen to eighteen per cent, compared with five to eight per cent for the Haber-Bosch process. The use of ordinary steel in Casale's converter was made possible by the forced cooling action on the inner casing of the converter shell of the mixed reactant gases, hydrogen and nitrogen, that were introduced under pressure (Figure 1). As a result of the very high pressure, the converter required a less active iron catalyst than needed for the German process. Surrounding the inner catalyst chamber was a concentric heat exchanger, providing heat for the incoming gases. Overheating in the region of the catalyst was prevented by allowing some ammonia to remain in the recirculated gases, thereby slowing the reaction down.

The process, for a given output, used smaller equipment than employed in the Haber-Bosch process. This also applied to the French process of Georges Claude, of Air Liquide, which was worked at 1,000 atmospheres. Moreover the energy requirements in the Casale and Claude processes were not much greater than required in units that were operated at considerably lower pressures. A major difference with Claude's high-pressure process was that the latter, as a result of its design, which

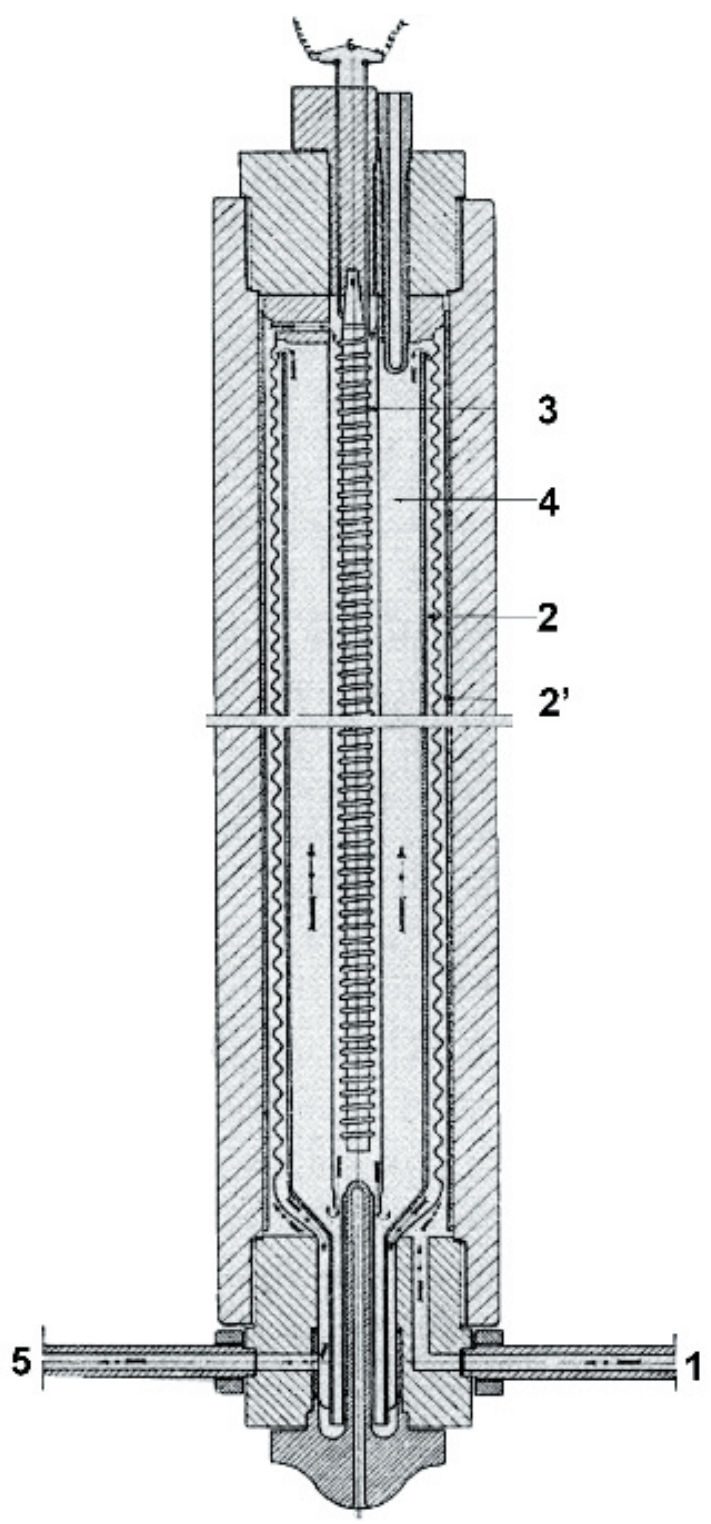

Figure 1. Casale ammonia converter (reactor), 1920s. Key: 1, gas (nitrogen-hydrogen) inlet; 2, 2', concentric annular spaces, divided by corrugated partition; 3 , electrical heater; 4, catalyst space; 5 , ammonia and unreacted nitrogen-hydrogen outlet. Redrawn from A. Miolati, Synthetic Ammonia and the Casale Process. Amplified edition of a lecture delivered the $27^{\text {th }}$ February 1927 at the Institute of Chemistry of the Polytechnic School of Prague (transl. G. Impallomeni, 2009). "L'Universale" Tipografia Poliglotta/Ammonia Casale SA, Rome, 1927, p. 24.

involved passage of reactant gases through a series of converters (without recirculation), required special steels in order to withstand the severe operating conditions. One important advantage of the two eponymous very high-pressure processes of Casale and Claude was that they gave directly anhydrous ammonia, in contrast 
to processes carried out under Haber-Bosch conditions which required expensive refrigeration equipment to achieve an anhydrous product.

Casale erected a pilot plant in an old iron works belonging to the Terni steelworks company (from 1922 Società per l'Industria e l'Elettricià Terni). In April 1921, he founded Ammonia Casale SA, in Lugano, Switzerland, which soon licensed the technology to entrepreneurs, companies, and state organisations in Japan and Europe. Though patents were filed in the United States, there was little interest in Casale's and other synthetic ammonia processes. America was well supplied with nitrogen products, through entrenched businesses and processes. Here we need to understand the background to the nitrogen fertilizer market in the United States.

\section{NITROGEN PRODUCTS IN THE UNITED STATES}

Three products enabled self-sufficiency in nitrogen compounds for use as fertilizers, and contributed to a healthy export trade in ammonium sulphate. The sulphate was the main nitrogen fertilizer, produced from the ammonia from by-product coking ovens that were rapidly replacing the beehive ovens from which valuable products were lost. In 1925, the United States ammonium sulphate capacity from many of the 10,000 by-product coking ovens was "well over 600,000 tons." Imported Chilean nitrate was widely used as fertilizer, notably in citrus growing regions. The third important source of fertilizer nitrogen was calcium cyanamide, as manufactured by the American Cyanamid Company on the Canadian side of the Niagara Falls from 1910.

During 1924-1925 the import of Chilean nitrate into the United States grew considerably, including through the involvement of the increasingly diversified Du Pont company. From the nitrate, Du Pont manufactured nitric acid, which was essential in production of explosives, dyes, and other products.

There was a new route to nitric acid, much used in Europe: catalytic oxidation of ammonia (the Ostwald process). Conversion of ammonia derived from cyanamide and from coking ovens into nitric acid using this process had been achieved just prior to World War I by, respectively, American Cyanamid, at Warners, New Jersey, and the Solvay Process Company, at Syracuse, New York. However the earlier method of making the acid starting with Chilean nitrate was generally favoured for both economic and technical reasons until the late 1920s. This is one reason why Du Pont had a not inconsiderable interest in the Chilean nitrate industry.

\section{Ammonia for Refrigeration}

In contrast to the situation in postwar Europe and Japan-where the synthetic ammonia industry was often backed by government self-sufficiency programmes related to both fertilizers and explosives-the early interest in synthetic ammonia in the United States was in supplying the more restricted refrigeration market. Ammonia was used as an industrial refrigerant well before World War I, notably by Armour \& Company of Chicago that was involved in meat packing and storage. The coal gas manufacturers were sources of aqua ammonia (ammonia water) used to produce the anhydrous ammonia for industrial refrigeration. Anhydrous ammonia was shipped in cylinders. From around 1890, the Harrisburg Pipe \& Pipe Bending Company manufactured the cylinders from hand-welded steel pipes. After 1910, following the lowering of an import tariff, seemless highpressure gas cylinders made by Mannesmann in Germany were imported into the United States. Harrisburg responded by producing a quenched and drawn heat cylinder of lighter weight, which could be handled by one man, instead of two as previously. In 1923, the production of anhydrous ammonia used in industrial refrigeration came to $23,966,000$ pounds, valued at $\$ 6,415,000 .^{7}$ Domestic refrigerators that relied mainly on sulphur dioxide for cooling were introduced later in the 1920s. ${ }^{8}$

Armour had pioneered large scale long-distance transportation of otherwise perishable foodstuffs in refrigerated railroad cars. This was far more important than in Europe, where transportation involved much shorter distances, and in generally cooler climates. Brewers were among the other important consumers of ammonia for refrigeration.

The leading distributor in the east was the National Ammonia Company, of St Louis, formed in 1889 at the initiative of Edward Mallinckrodt, of the Mallinckrodt Chemical Works, by merger of five large producers of ammonia (subsequently other companies in the ammonia business were acquired). By the early 1900s there were factories in both St Louis and Philadelphia, and branches in Canada and Australia, offering both anhydrous and aqua ammonia. On the west coast, the Pacific Ammonia \& Chemical Company, managed by Robert P. Greer, monopolised the market in anhydrous and aqua ammonia. Pacific Ammonia, founded in San Francisco in the 1890 s, moved its manufacturing base to Seattle in 1908-1909. By 1920, it was represented by agencies in Japan, China, the Philippines, the Hawaiian Islands, and British Columbia. In 1922, Pacific Ammonia became associated with National Ammonia; the two stockholders in Pacific Ammonia, with almost equal holdings, were 
National Ammonia and Robert Greer. National Ammonia retained its strong interest in distributing ammonia to the refrigeration market, but did not compete with producers and distributors of nitrogen fertilizers.

\section{The FNRL and Its 3-Ton Per Day Ammonia Unit}

Despite the range of commercial nitrogen products available in the United States, interest in high-pressure ammonia processes and general nitrogen fixation was certainly not lacking. From March 1919, the role of synthetic nitrogen compounds as fertilizers and in production of nitro compounds for munitions were investigated at the state sponsored Fixed Nitrogen Research Laboratory (FNRL) in Washington DC, under the aegis of the U.S. Army's Nitrate Division. During 1919, American military officers visited the BASF ammonia facility at Oppau, in the French zone of occupation. Though they were not always welcome, they made useful observations, and, probably surreptitiously, procured samples of catalysts, that ended up on the test benches of the FNRL. ${ }^{9}$ In just over half a decade, its staff resolved most of the chemical and technical problems related to the ammonia synthesis. Thus, Alfred T. Larson developed a catalyst similar to that used in the Haber-Bosch process, no doubt based on analysis of samples obtained from Oppau, and patents for German recipes. This contributed to the success of the FNRL in producing synthetic ammonia, at around 200 atmospheres pressure, drawing on pure hydrogen obtained by electrolysis of water in cells provided by the Electrolabs Company of Pittsburgh. ${ }^{10}$

From 1924, the results of the FNRL were made freely available to chemical firms and entrepreneurs; many of its chemists subsequently contributed to the US synthetic nitrogen industry. ${ }^{11}$ Larson, for example, joined Du Pont. The FNRL's 3-ton per day (tpd) synthetic ammonia unit became a model for a handful of American firms, all working on a small scale. The most expensive input was hydrogen, for which operators of the FNRL process relied mainly on by-product hydrogen from electrochemical processes in locations where abundant hydroelectric power was available. First to adopt the FNRL process, in 1924, was the Pacific Nitrogen Corporation, at the Seattle works of Pacific Ammonia (then associated with National Ammonia). The entire installation was erected under the supervision of FNRL staff. In this case, dedicated cells produced the hydrogen, which was far more costly than by-product hydrogen. Next, during 1924-1925, was the Mathieson Alkali Works, at Niagara Falls, followed in 1926 by the Roessler \& Hasslacher Chemical Company, also at Niagara Falls
(Table 1). ${ }^{12}$ These firms manufactured ammonia for the refrigeration market or for use in production of other chemicals. Thus, Roessler \& Hasslacher relied on inhouse by-product hydrogen from electrolytic production of sodium, and used the ammonia to manufacture sodamide (sodium amide), for its sodium cyanide process. The small scale of working with FNRL type units, as compared with manufacture in Europe and Japan, did not permit economic production of nitrogen fertilizers.

At best, the FNRL had aided in the creation of a minor branch of chemical industry. However, nitrogen fertilizers based on synthetic ammonia required large-scale operations and economies of scale. This was achieved in Europe by merging the two cultures of engineering and chemistry. Ammonia Casale SA was a front runner in this endeavour.

\section{CASALE IN AMERICA}

Here we turn to the story of the introduction into the United States of the Casale ammonia process. Luigi Casale not only promoted and, unlike BASF, licensed his process but also served as a contractor, supplying Italian made converters, compressors, and associated equipment to clients. At first there were no rivals: Claude's process faced difficulties with converters; and the Italian process of Giacomo Fauser, under Montecatini, was confined to Italy. The first licensee of Ammonia Casale SA was Noguchi Shitagau (founder of the Nitchitsu corporation) in Japan, who met with great success and within a short time was ordering additional converters. Casale converters were put to work in Belgium, France, Switzerland, Spain, and elsewhere. ${ }^{13}$ Figures of nitrogen consumption in the United States clearly suggested to Luigi Casale that here was an untapped and potentially vast market for synthetic ammonia, including for use in refrigeration. In 1923, following the filing of certain key patents on his inventions, Casale set about the creation of a new enterprise, Niagara Ammonia Company, Inc., established in New York City. This American branch of Ammonia Casale SA would not only engage in licensing arrangements and the supply of equipment, but would also undertake manufacture on American soil, using converters and compressors imported from Italy. Casale's Niagara Ammonia would not only be a showpiece for Americans to admire, but its product, usefully, would not be subject to import tariffs on ammonia.

Ammonia Casale SA also established in New York The Ammonia Corporation (Figure 2). It retained ownership of the Casale patents in the United States. ${ }^{14}$ Also involved, as an assignee jointly with Luigi Casale of cer- 
Table 1. Synthetic ammonia facilities, United States, 1927.

\begin{tabular}{|c|c|c|c|c|}
\hline Name & Location and process & $\begin{array}{l}\text { Rated daily capacity, } \\
\text { tons of ammonia }\end{array}$ & $\begin{array}{l}\text { Daily operating rate, } \\
\text { tons of ammonia }\end{array}$ & $\begin{array}{l}\text { Yearly nitrogen } \\
\text { equivalent in tons } \\
\text { (based on } 350 \text {-day } \\
\text { operation) }\end{array}$ \\
\hline Atmospheric Nitrogen Corp. & $\begin{array}{c}\text { Syracuse, NY (Solvay/Allied), General } \\
\text { Chemical }\end{array}$ & 30 & 30 & 7,750 \\
\hline Lazote, Inc. (Du Pont) & Charleston W. Va. (Belle), Claude & 25 & 15 & 4,350 \\
\hline Mathieson Alkali Works & $\begin{array}{c}\text { Niagara Falls, NY. } 3 \text { tpd in } 1925 \text {, } \\
\text { American }\end{array}$ & 10 & 10 & 2,900 \\
\hline $\begin{array}{l}\text { Niagara Ammonia Company (to Du } \\
\text { Pont, 1927; ceased operating July } \\
\text { 1927) }\end{array}$ & Niagara Falls, NY, Casale & $13(17)$ & 8 & $\begin{array}{l}1,250 \text { (approximately } \\
\text { six months) }\end{array}$ \\
\hline $\begin{array}{l}\text { Roessler \& Hasslacher Chemical Co. } \\
\text { (to Du Pont 1930) }\end{array}$ & Niagara Falls, NY, American & $\begin{array}{l}3 \text { (increased to } 9 \\
\text { tons, 1928) }\end{array}$ & 3 & 865 \\
\hline $\begin{array}{l}\text { Pacific Nitrogen Corp. (to Du Pont } \\
\text { 1927) }\end{array}$ & Seattle, Washington, American & 3 & 3 & 865 \\
\hline Great Western Electrochemical Co. & Pittsburg, California, American & 1 & 1 & 290 \\
\hline Commercial Solvents Corp. & $\begin{array}{c}\text { Peoria, Ill. Southwest of Chicago, } \\
\text { American }\end{array}$ & 15 & 0 & $\begin{array}{l}\text { Converted to } \\
\text { methanol, shortly } \\
\text { after inauguration in } \\
1927 .\end{array}$ \\
\hline
\end{tabular}

Sources: F. A. Ernst, Fixation of Atmospheric Nitrogen, Chapman \& Hall, Ltd., London, 1928, p. 121. F. A. Ernst, F. C. Reed, W. L. Edwards, "A Direct Synthetic Ammonia Plant," Industrial and Engineering Chemistry, August 1925, 17(8), 775-788. Editorial, Industrial and Engineering Chemistry, August 1925, 17(8), 772. F. A. Ernst, M. S. Sherman, “The World's Inorganic Nitrogen Industry," Industrial and Engineering Chemistry, February 1927, 19(2), 196-204, on 199. Notes: American = based on the Fixed Nitrogen Research Laboratory (FNRL) method. The original source of hydrogen at Syracuse was water gas, until May 1927, when in house by-product hydrogen became available. Niagara Ammonia Company used its electrolytic cells for generating hydrogen, as well as purchasing by-product hydrogen from the adjacent Hooker Electrochemical plant. Pacific Nitrogen used electrolytic hydrogen from its dedicated cells; Mathieson and Great Western used byproduct electrolytic hydrogen. Commercial Solvents used by-product hydrogen from fermentation.

tain of Casale's patents, was René Leprestre, who was based, in part at least, in New York. The Ammonia Corporation assigned patent rights and provided funding to Niagara Ammonia; they were to share any licensing compensation.

Reports of successful operation of the Casale process must have gone a long way towards convincing American investors, especially those with interests in electrical power, to back Casale. As a result, the principal external backer was the Electric Bond \& Share Company, a major utilities trust originally founded by General Electric in 1905. ${ }^{15}$

Around four-fifths of both preferred and common stock in Niagara Ammonia were held by The Ammonia Corporation, while around one-fifth of the stock was held by Electric Bond \& Share, represented by the banker and entrepreneur Henry J. Pierce (1859-1947). ${ }^{16}$ The Electric Bond stock was held in the name of nominee Frank L. Smiley (1871-1948) a dealer in utilities stocks. Ammonia was in some ways an unusual investment for Electric Bond \& Share, which was mainly involved in power stations and electrical infrastructure, including interurban and street railways. However, the chemical industry was a major, and rapidly growing, consumer of electricity, and synthetic ammonia, which relied on electrically powered machinery, no doubt offered a novel area for diversification. (The interest in synthetic ammonia at Electric Bond \& Share, later EBASCO, continued until well after World War II.)

Other investors included the New York stockbroking houses A. Iselin \& Company, which had close connections with Europe, and H. T. Carey \& Company. There was also David Barker Rushmore, an engineer formerly at General Electric, and an enthusiast for hydroelectric power generation. In 1923, Rushmore published the second edition of a book, co-authored with Eric A. Lof, on power stations. ${ }^{17}$ In the same year, Lof drew up a report on atmospheric nitrogen fixation. The Iselin firm held the stock certificates of Ammonia Casale SA investments in the United States.

To all intents and purposes, the aspirations of The Ammonia Corporation were based on a business plan 


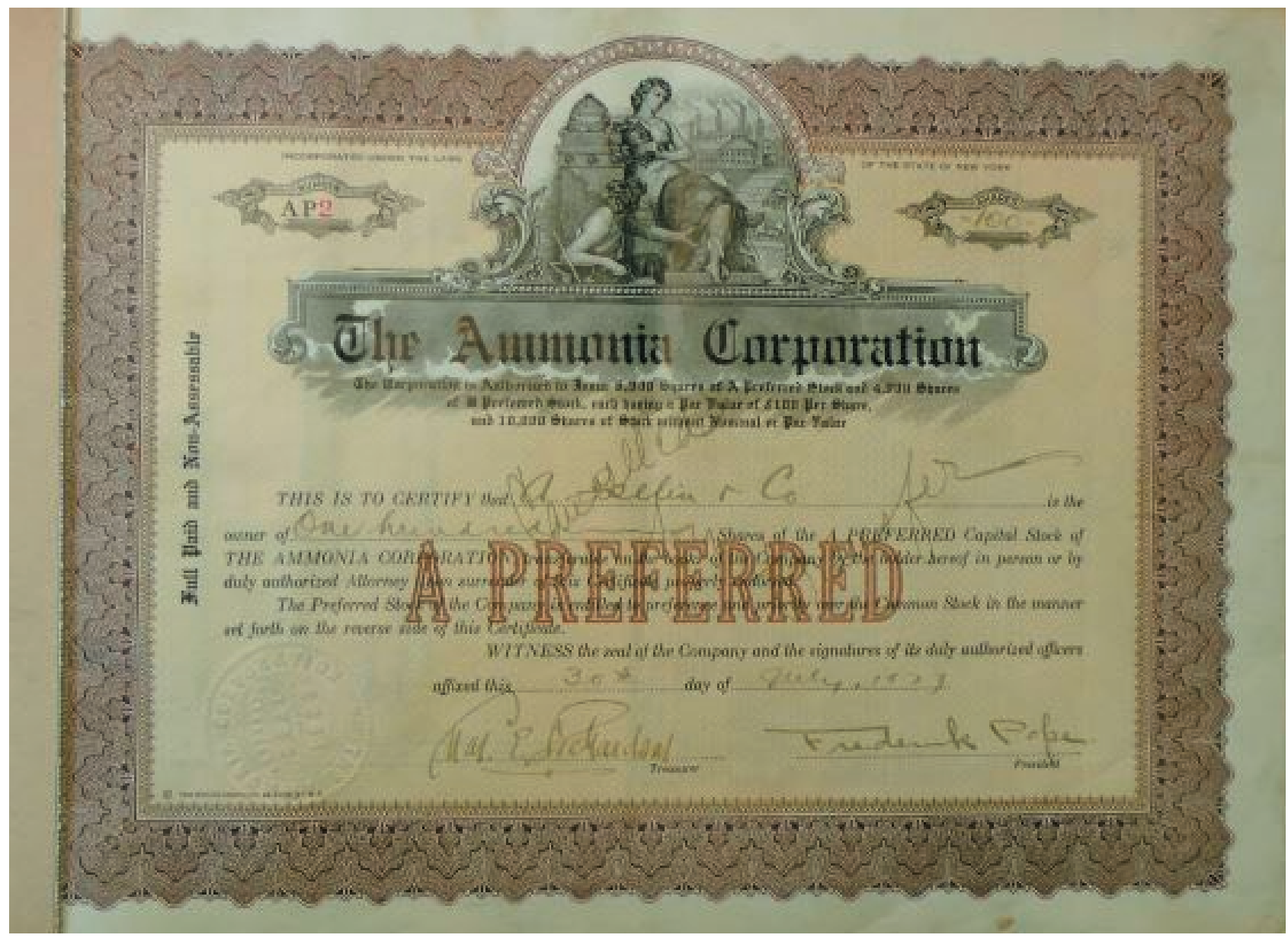

Figure 2. Stock certificate, The Ammonia Corporation, preferred stock, assigned to A. Iselin \& Co., 30 July 1923 . Iselin held the stock certificates of Ammonia Casale SA holdings in The Ammonia Corporation and the Hydro-Electric Chemical Company. From: The Ammonia Corporation, A Preferred Stock. Records of E.I. Du Pont de Nemours \& Co. Absorbed companies. Manuscripts and Archives Department, Hagley Museum and Library, Wilmington, Delaware, Accession 500, series II, part 1, box 67. Author's photograph. Reproduced with permission.

aimed at marketing the Ammonia Casale brand in North America, underpinned by proven success, and patent protection. In terms of rated converter capacity, of around 7-8 tpd, the Casale process certainly offered far more than the processes based on the Fixed Nitrogen Research Laboratory's 3-tpd unit, which in 1923 had not yet been introduced on an industrial scale, and the then problematic Claude process. The only viable rival was the General Chemical Process, of Allied Chemical, which was confined to Solvay operations at Syracuse (See next section). The Ammonia Corporation, it must have seemed, stood to benefit from growth in demand for nitrogen products, including, the founders probably anticipated, the fertilizer market, that would bring in substantial royalties following the signing of licensing agreements. This differed from arrangements elsewhere, in which sole licenses for given countries or geographical regions were sold to chemical manufacturers, without, it appears, direct investment from Ammonia Casale.

\section{THE GENERAL CHEMICAL PROCESS}

The first attempt to introduce a catalytic high-pressure synthetic ammonia process in the United States was made by the General Chemical Company (a consolidation of twelve companies established in 1899), just prior to the outbreak of war in Europe. Much interest had been generated after the demonstration by BASF of Haber's method at the Eighth International Congress of Applied Chemistry, held in New York in 1912. This was followed by careful scouring of the available litera- 
ture and patent applications concerning the process. At General Chemical, Frederick W. de Jahn and colleagues developed a process similar to that of BASF, and discovered an iron catalyst incorporating sodamide. The company put together a small pilot plant during 1915-1916. Subsequent government supported wartime experimental work based on the process was not successful. However, by 1919 these studies enabled General Chemical chemists to overcome several technical problems, including a suitable steel for the converter shell, and devise an improved catalyst. ${ }^{18}$

In late 1919, General Chemical and the Solvay Process Company brought together their interests in synthetic ammonia through the Atmospheric Nitrogen Company, in order to set up an ammonia unit at Solvay's Syracuse works.

The development of the General Chemical process benefitted greatly from the free exchange of technical information between Solvay Process and the British firm Brunner, Mond \& Company, in accord with arrangements dictated by the Belgian licensor of the Solvay ammonia-soda process, Solvay et Cie. This included details of the catalyst used in the Haber-Bosch process, samples of which were taken by Brunner, Mond investigators during their visits to Oppau in 1919. ${ }^{19}$

In 1920, General Chemical, Solvay Process, and five other firms, including National Aniline \& Chemical (a merger of four firms dating from 1917), were absorbed into a new behemoth, Allied Chemical \& Dye Corporation. This was one of the first major interwar mergers in the chemical industry, preceding those that led to I.G. Farben (1925), and Britain's ICI (1926). It was in many ways a response to concerns arising from the fact that $\mathrm{Du}$ Pont and BASF had begun discussions on the opening of a Haber-Bosch facility in the United States, much to the chagrin of General Chemical and Solvay Process, who were anticipating collaboration with BASF in a similar venture. In the end, Du Pont failed in its dealings with BASF, and for a while lost interest in synthetic ammonia. ${ }^{20}$

On 8 August 1921, Atmospheric Nitrogen started up what became known as the General Chemical synthetic ammonia process at Syracuse. The initial rated output was 9-tpd. The source of hydrogen was water gas, obtained by the reaction between steam and red hot coke, the latter available from Semet-Solvay coking ovens. This followed the success of BASF and Brunner, Mond with water gas processes.

Nitrogen was initially obtained by air liquefaction. In September 1921, William Henry Nichols, chairman of Allied Chemical, "caused a deal of surprise" when he announced this considerable achievement at a luncheon during the American Chemical Society's 62nd meeting, held at Columbia University. ${ }^{21}$ In 1922, however, the German observer Bruno Waeser suggested that the process was facing technical difficulties. ${ }^{22}$ Moreover, the Syracuse anhydrous ammonia was not at first well suited to refrigeration due to the presence of impurities, as a result of which distillation equipment had to be introduced. Some ammonia was probably used to produce sodamide for the Allied Chemical synthetic indigo process, and for manufacture of sodium cyanide. Its potential for use in the Solvay ammonia-soda process was also significant.

Published figures of the rated annual output of Syracuse ammonia indicate growth from 3,000 tons in 1921 to 7,750 tons in the mid-1920s. ${ }^{23}$ This increase took place following the decision of the head of Allied Chemical, Orlando Weber, to invest heavily in synthetic ammonia and inorganic products at the expense of dyes and other organic chemicals. ${ }^{24}$ Allied Chemical's ammonia process was not made available for licensing. By 1925, Allied Chemical had embarked on construction of a large synthetic ammonia facility, using the modified General Chemical process, at the new Hopewell, Virginia, factory of Solvay Process. It opened in late 1928, and relied for hydrogen on water gas made from coke brought in from Allied's remote coking ovens. The first product made at Hopewell was anhydrous ammonia, soon followed by the fertilizers ammonium sulphate and sodium nitrate. For the first time in the United States, economies of scale enabled synthetic ammonia to compete in the agricultural fertilizer market with Chilean nitrate, coking oven and gas works by-products, and calcium cyanamide.

According to historian of the US chemical industry Williams Haynes the Syracuse ammonia unit continued in service, as had been the case earlier, as a pilot facility for process development, while markets for synthetic ammonia were being investigated..$^{25}$ However, with downsizing, following construction at Hopewell, there was an alternative source of hydrogen at Syracuse. From May 1927, the new Solvay electrolytic plant there supplied by-product hydrogen for the synthetic ammonia unit, in addition to chlorine for dye manufacture at the nearby factory of National Aniline (part of Allied Chemical), and caustic soda for local manufacturers of artificial silk (viscose). For development purposes, there were advantages in employing electrolytic hydrogen. It was pure, unlike that from the water gas process (which required extensive purification to prevent poisoning of catalyst). Also, reliance on electrolytic hydrogen permitted intermittent, small-scale, operation, unlike the cokebased processes. These factors were also important in 
deciding the source of hydrogen at the FNRL, and also at Casale's American factory. The Syracuse experimental unit continued to operate until well into the 1930s. ${ }^{26}$

\section{AMMONIA CASALE SA IN AMERICA}

The function of the Niagara Ammonia Company, as its name might suggest, was to operate the Casale process at Niagara Falls, the hub of the US electrochemicals industry. In this connection there was also an associated Casale enterprise, again with the close involvement of Electric Bond \& Share, the Hydro-Electric Chemical Company, founded in Maine in July 1923 (Figure 3). Hydro-Electric's holding company was the Chemical Investment Corporation, also established in 1923 (Table 2). ${ }^{27}$ The president of Hydro-Electric Chemical was Henry J. Pierce, again representing Electric Bond \& Share. Among the investors (and later a director) was the New York lawyer Josiah Turner Newcomb, the special coun- cil for Electric Bond \& Share. A director, and holder of a single share, was René Leprestre. The interests of Electric Bond \& Share and Ammonia Casale in America were now closely intertwined. Together they embarked on an ambitious venture aimed at dominating certain novel and emerging sectors of the US chemical industry, based on electrochemicals and high-pressure technology.

\section{Colonel Frederick Pope}

The president of both The Ammonia Corporation and Niagara Ammonia was the Harvard educated chemical engineering consultant and entrepreneur Colonel Frederick Pope (1877-1961), a resident of New York. ${ }^{28}$ Before 1914, following stints in mining operations, including in South Africa, Pope had studied aromatic nitro compounds, those used to make modern explosives and synthetic dyes. During World War I, it was later claimed, he opened the first new American synthetic dye

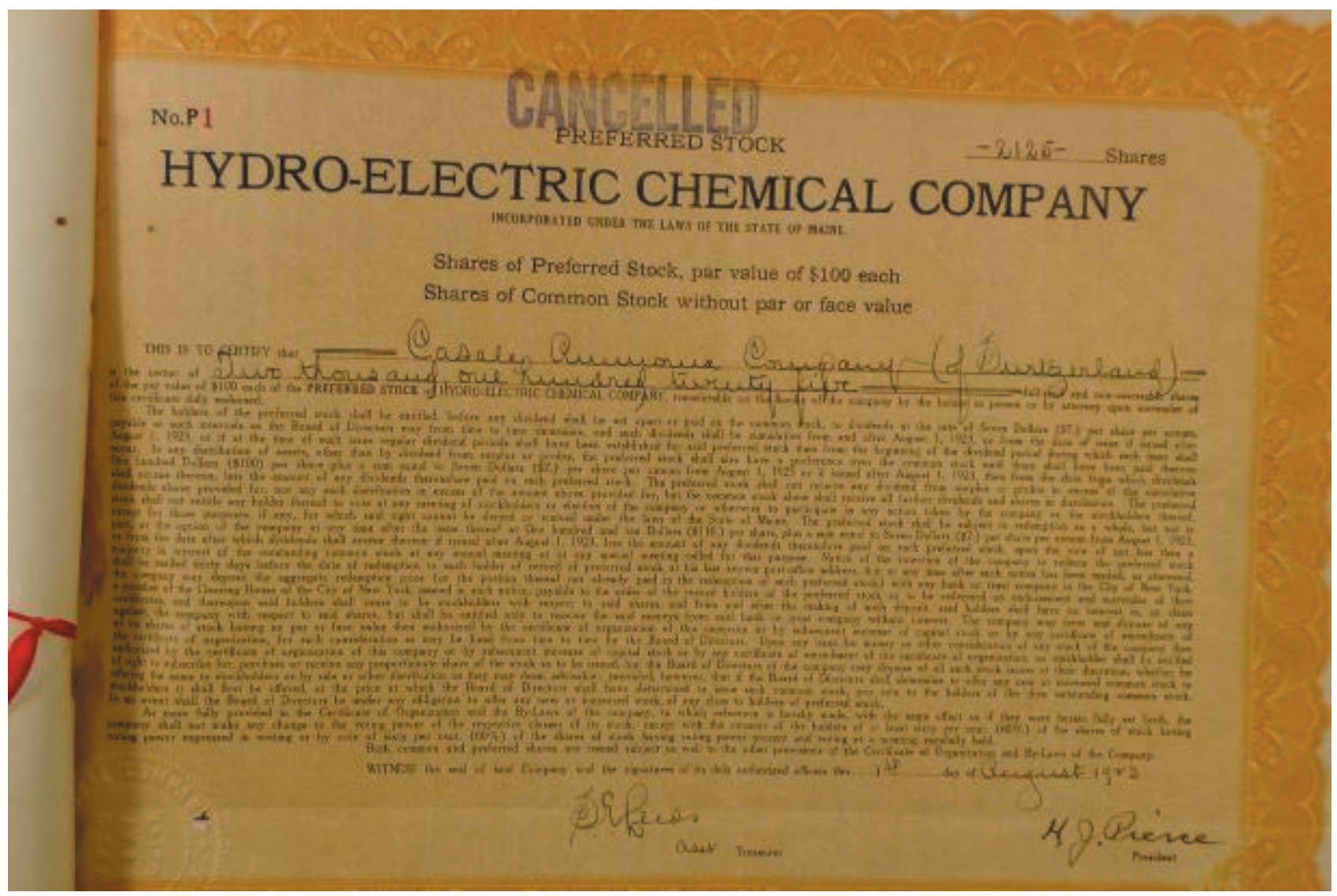

Figure 3. Stock certificate, Hydro-Electric Chemical Company, preferred stock, in the name of the Casale Ammonia Company (often used in English language documents for Ammonia Casale SA), 1 August 1923. From: Hydro-Electric Chemical Company, Stock Certificate book, 1923-28. Records of E.I. Du Pont de Nemours \& Co. Absorbed companies. Hagley Museum and Library, Wilmington, Delaware, Accession 500 , series II, part 1, box 848 . Author's photograph. Reproduced with permission. 
Table 2. Ammonia Casale SA investments in the United States, 1923-1927.

\begin{tabular}{|c|c|c|c|c|}
\hline Holding corporation & Affiliate & $\begin{array}{l}\text { Place and year of } \\
\text { foundation }\end{array}$ & $\begin{array}{c}\text { Date of transfer of stock to } \\
\text { Du Pont }\end{array}$ & Fate \\
\hline \multirow[t]{2}{*}{ The Ammonia Corporation } & & New York, 1923 & May-June 1927 & Bankrupt, February 1928 \\
\hline & Niagara Ammonia Co., Inc. & New York, 1923 & May-June 1927 & Bankrupt, February 1928 \\
\hline \multirow[t]{2}{*}{$\begin{array}{l}\text { Chemical Investment } \\
\text { Corporation }\end{array}$} & & 1923 & 1927 & \\
\hline & $\begin{array}{l}\text { Hydro-Electric Chemical } \\
\text { Company }\end{array}$ & Maine, 1923 & $\begin{array}{l}\text { October } 1927 \text { (to Lazote } \\
\text { December 1927) }\end{array}$ & \\
\hline
\end{tabular}

Notes:

The Ammonia Corporation: In 1923, Ammonia Casale SA held 2,000 shares of preferred stock, and 3,050 shares of common stock, in The Ammonia Corporation.

Niagara Ammonia Co., Inc.: The second largest stockholder was Frank L. Smiley, nominee for Electric Bond \& Share Company, whose holdings were transferred to Du Pont in May 1927.

Hydro-Electric Chemical Company: The authorised capital was $\$ 750,000$, with 20,000 shares non par. Ammonia Casale SA held 2,125 of preferred stock, and 7,840 of common stock. The Chemical Investment Corporation, the holding company for Hydro-Electric Chemical, held 5,000 preferred stock, out of a total of 7,500 (later increased to 9,000), and 10,191 common stock. A major stockholder in the HydroElectric Chemical Company was Bonn \& Co., whose holdings were transferred to Lazote in 1929.

factory, prior to specialising in gas warfare in the United States and France. In 1918, before the cessation of hostilities, he took from England to the United States details of the technology for producing mustard gas by the Levinstein process, which was taken up at Edgewood Arsenal. In 1919, he was among the technical experts who visited German chemical factories, in his case twice, to follow up developments in organic chemical and dye manufacture and the production of toxic chemicals. Pope's brief published account does not indicate the sites that he visited, though they probably included the synthetic ammonia facility of BASF at Oppau. ${ }^{29} \mathrm{His}$ Chemical Warfare Service colleague Theodore Sill visited Oppau, which he described as a wonder of modern technology. What Pope saw or heard about Oppau must have aroused in him an interest in the potential for highpressure industrial chemistry. ${ }^{30}$ Above all, it was Colonel Pope's status as an experienced entrepreneur, with an extensive network of contacts, that recommended him to the American Casale enterprise.

\section{HYDROGEN FOR NIAGARA AMMONIA}

As with all synthetic ammonia processes, the main operational cost was associated with production of hydrogen, at first obtained by electrolysis in locations where abundant hydroelectric power was available. On the United States side of the Niagara Falls firms such as Hooker Electrochemicals manufactured chlorine, alkali and chlorinated organic compounds, as well as making available by-product hydrogen, from its electrolysis process. In 1918, Hooker first supplied hydrogen to a joint enterprise, Hydrofats., Inc., for hardening vegetable oils. ${ }^{31}$ Hydrofats, located on Hooker's land next to the latter's Niagara Falls factory, ceased operating in 1922. In the following year, the former Hydrofats site was leased by Hooker to Niagara Ammonia, whose directors included Willard E. Hooker, youngest son of the founder of Hooker (Elon Huntington Hooker, 1905).

In November 1923, a contract with Electrolabs for purchase of a hundred and sixteen of its 5,000 amp cells, including their installation, at a cost of $\$ 40,356$, was approved, as was a contract with the General Electric Company for "motor generators, exciters, switchboards, etc., being the complete apparatus to furnish direct current at the proper voltage to the cells, for the sum of \$45,308:00." Niagara Ammonia director A. E. Bonn, previously at American Cyanamid, reported that the Electrolabs cells at the FNRL "had been entirely satisfactory." (Bonn, through Bonn \& Company, was an investor in the American Casale enterprises.) Also, it was reported that the two-month old Casale ammonia plant in Japan was so successful that an order had been placed for two additional converters, each with a rated daily capacity of $71 / 2$ tons of ammonia. Hydroelectricity from the Niagara Lockport \& Ontario Power Co. (which was independent of Electric Bond \& Share) drove all machinery at Niagara Ammonia, including compressors and circulation pumps, and provided power for the electrolysers. Niagara Lockport also supplied electricity to the Syracuse factory of Solvay Process.

The source of nitrogen for the ammonia process was based on another of Luigi Casale's inventions, the removal of atmospheric oxygen from air by its reaction with hydrogen, the so-called burning of air. ${ }^{32}$ 
To protect the considerable investment in highpressure chemistry, that would soon reach well over half a million dollars, the board of Niagara Ammonia discussed acquisition of a license for a German synthetic ammonia process from the Chemical Foundation, Inc., which held sequestered German patents on a number of nitrogen processes as well as on synthetic organic chemicals. ${ }^{33}$ This would be of value to Niagara Ammonia should the Casale patents in the United States come under threat through litigation arising from patent disputes. The precaution was justified. This was still the start-up period, based on a relatively new industrial technology, with unknown risks, at least in the United States: "It was the consensus of opinion that approval to the taking out of that license [from the Chemical Foundation] should be be given only as a measure of defense, since the Casale patents under which this Company would operate, have not as yet been the subject of judicial determination and there are certain claims which might give rise to litigation and the consequent expense and loss... approval was deemed wise as a matter of business precaution." The drawing up of a contract with the Chemical Foundation was "unanimously approved." ${ }^{4}$

In December 1923, Frederick Pope, in his role as president of Niagara Ammonia, reported that progress in construction work at the Niagara Falls site was satisfactory. The first consignment of machinery had arrived from Italy. Bonn advised that there might be some delay in receiving a second seaborne shipment of machinery from Italy, and that there "is a substantial amount of machinery on the third boat." ${ }^{35}$ The machinery included Casale converters, probably manufactured at the Terni steelworks. An alternative source was the Italian works of Armstrong SA, a subsidiary of the British engineering firm Armstrong Whitworth, at Pozzuoli, in southern Italy, that manufactured Casale converters for installation at the Nera Montoro synthetic ammonia factory, located near Terni. ${ }^{36}$ Also from Italy were the special high-pressure compressors, manufactured by the firm of Pignone, of Florence, and circulation pumps. In 1922, Pignone introduced the first commercial multistage compressor suited to the synthesis of ammonia under Casale's operating conditions.

During May 1924, Niagara Ammonia first received by-product hydrogen from Hooker. ${ }^{37}$ Though Niagara Ammonia intended to generate its own supply of hydrogen from the in-house electrolysers, the availability of hydrogen from Hooker was a useful reserve supply.

On July 30, Pope reported that this was the first occasion when he could report actual production, "the plant having operated off and on during the month of July, making about 72,000 pounds of ammonia, which at $15 \notin$ a pound, amounts to $\$ 10,800$." The monthly bill for hydrogen was approximately $\$ 5,000$. The payroll was about $\$ 4,000$, and cost of supplies $\$ 600$. Pope believed that "the plant profit, excluding overhead and sales expenses, could be about $\$ 1,000 . " 38$

However, Niagara Ammonia was forced to delay sale of its anhydrous ammonia until quality issues had been dealt with. Pope drew attention to the fact that for use as refrigerant the anhydrous ammonia was unacceptable to an important potential customer, and distributor, Armour \& Company, "as it contained more than the allowable percentage of water and foreign gases." This difficulty could be overcome by the installation of a distilling apparatus, costing between ten and fifteen thousand dollars. The decision to install suitable distillation equipment was based on a report from D. T. Kiley of Armour \& Company, whose chief chemist, J. R. Powell, visited the Niagara Ammonia factory. Kiley's report revealed the difficulties involved in producing ammonia for the refrigeration market, and not just at Niagara Ammonia.

Our chief chemist, Mr Powell, has returned from Niagara Falls and I am enclosing to you a copy of his report. You will see that it is going to be necessary for you to put in another still. The Syracuse people [Allied Chemical/ Solvay Process] had the same trouble and their ammonia was condemned by the trade until after they had installed an extra still to put out an anhydrous ammonia that was equal to that made by other manufacturers.

I know that you will go into this at once, as you personally know that should we send out any ammonia that was not fully equal to that made at Syracuse, the Niagara ammonia would get a 'black eye' that would take a long while to get over and our competitors would take advantage of it. You may rest assured that the first ammonia we put out will be watched closely and they will all be buying cylinders and testing the ammonia and if it isn't 'up to snuff', you can bet the consumers are going to know about it through them.

Powell found contamination of the anhydrous product with moisture and foreign gas that was three or four times greater than required of an ammonia suited to the exacting requirements of the refrigeration market. An Italian representative of Ammonia Casale had been on hand during Powell's visit and "seemed thoroughly convinced that the source of the water was the accidental introduction of small amounts of oxygen with the gases before they entered the system." 39

Colonel Pope observed that Henry Pierce, as a member of the Niagara Ammonia board, "has been of great service to the company while abroad, in urging Dr. Casale to come to the United States the middle 
of August, and in following the delivery of the Italian machinery for the third unit of our plant." If the three units were identical, this indicates, on the basis of published reports of rated capacities, that each one was of around 7-tpd capacity. On the same occasion, funds were approved for completion and "tuning up" of the first unit. ${ }^{40}$

Not long after, Luigi Casale visited the United States to deal with his business interests there. According to Casale's professor, Arturo Miolati, Casale attended an event with Fritz Haber in New York, which must have been around the time of the Benjamin Franklin centenary celebrations, held in Philadelphia during September 17-19, where Haber was a speaker. ${ }^{41}$

\section{CHANGES AND CHALLENGES AT NIAGARA AMMONIA}

\section{The Departure of Fredrick Pope}

On 14 November 1924, Colonel Frederick Pope tendered his resignation, as president, of Niagara Ammonia, and apparently of other Casale interests, and was replaced by Henry Pierce. On the same occasion, anticipating substantial investment in scaling up, or at least in making improvements, it was resolved that the "president be authorized to borrow from The Ammonia Corporation the sum of $\$ 150,000$, in such amounts as might be required, upon this company's notes, at the rate of $6 \%$ per annum." ${ }^{\prime 2}$ By early 1925, Willard Hooker had been appointed a vice president of Niagara Ammonia. ${ }^{43}$

Pope perhaps foresaw difficulties, including the great expense of generating hydrogen from electrolysers at the Niagara Falls operation. ${ }^{44}$ That may have suited Europe and Japan, where strong political and strategic commitments and local and state support were significant factors in the adoption of hydroelectric power. In the United States, electricity, though widely available, was expensive. Very few additional electrolysers were installed at Niagara Ammonia. The actual output of synthetic ammonia never exceeded 8-tpd, which was considerably less than the combined rated capacities of the converters.

Lured away by new challenges, Pope's experience at Niagara Falls, and of the new synthetic ammonia technology of Luigi Casale, was timely and put to good use. Pope became involved in the Nitrogen Engineering Corporation (NEC), founded in 1926, which offered an ammonia converter based on a process that was far better adapted to large scale production than the so-called "American" process of the FNRL. The co-inventors of the NEC process, Louis C. Jones and Major Charles O. Brown, had previously been employed by Allied Chemi- cal. Pope also became associated with the Chemical Construction Company (Chemico), an engineering firm based in Charlotte, North Carolina, that in 1929 acquired NEC, and held patents on novel catalytic processes, including the Selden vanadium catalyst for sulphuric acid, and that had developed a process for oxidation of ammonia to give nitric acid. In 1930, Chemico was acquired by the American Cyanamid Company. Cyanamid's Chemical Construction Corporation (still referred to as Chemico), offered design and construction services for high-pressure plant, and other equipment. Around 1930, Pope was involved in introduction of the NEC process in the Soviet Union, perhaps after convincing the Russians that it was better suited to their conditions than the Casale process (which was introduced at one site in Russia in 1928). In June 1932, at a time when the Soviet Union was anxious to gain diplomatic recognition from the United States, the Russians managed to gain his assistance. ${ }^{45}$ However, Pope's relationship with the Russians was not smooth. He ceased dealing with them in $1934 .{ }^{46}$ Later, he was closely associated with attempts to introduce American Cyanamid's (Chemico) chemical technologies in China, Mexico, Egypt, and elsewhere.

\section{The Hydro-Electric Chemical Company and the Liljenroth Process, and Royalties on Ammonia}

In 1924, an interest in production of mixed nitrogen-phosphorus fertilizers, and at the same time a new source of hydrogen, led Hydro-Electric to back the electrothermal phosphoric acid-hydrogen method of Frans Georg Liljenroth, of Stockholm, Sweden. Phosphorus, produced by reduction of phosphate rock in an electrically heated furnace, was reacted with steam to afford phosphoric acid and hydrogen. The Phosphorus-Hydrogen Company had been established in New York to promote the process in the United States, and during 1925 began experimental work at the Niagara Ammonia factory. Chemist Thomas Edward Warren, who worked at Niagara Falls on the Swedish process in 1925, recalled that the intention was to move away from ammonia for use in refrigeration towards synthetic fertilizers, in particular ammonium phosphate, and phosphoric acid, as well as generating hydrogen from the Liljenroth process for use in the ammonia process. ${ }^{47}$ However, the Liljenroth process was not taken up in practice.

Hydro-Electric, like Niagara Ammonia, also promoted the Casale process. One item in its correspondence file is of interest for revealing the royalty rates, and also the difficulty in finding licensees. During 1925, the royalty on the Casale process was fixed at 5 dollars per 
ton. On 9 December 1925, the board of Hydro-Electric discussed a reduced royalty, to be "granted by this Company at any time within two years from and after the date of this meeting, the royalty rate to be fixed ... at not less than $0.4 \phi$ per pound of $\mathrm{NH}_{3}$." Board member Charles Hardy voted against this proposal because he considered that it was not good for business to reduce the royalty rate from 5 dollars per ton until the latter "had been refused by some of the prospective licensees" (of which there were few, if any). ${ }^{48}$

The discussion on royalty rates had been stimulated by the abrupt 50 per cent fall in the price of anhydrous ammonia late in 1925. The price of aqua ammonia also fell, though less sharply. This encouraged widespread oxidation of ammonia into nitric acid, and the use of the acid in manufacture of sulphuric acid, in particular using processes developed by Du Pont and Chemico. ${ }^{49}$ However, this hardly helped Niagara Ammonia and other companies that relied on sales of synthetic ammonia for the industrial refrigeration market. They had a hard time matching the price of ammonia from the other sources. ${ }^{50}$ By 1926, the ammonia suppply industry in general was suffering from severe competition and a glut. The Niagara Ammonia Company, operating at less than half capacity, faced an uncertain future, and not just as a result of an increasingly difficult trading environment.

In March 1926, at a meeting of the directors of Niagara Ammonia, it was revealed that the company was in debt to the tune of $\$ 600,000$, for one loan, and $\$ 25,000$, for a second loan, to The Ammonia Corporation. The repayment dates for both loans were extended from April 1st to May 20th. ${ }^{51}$ On May 17 th, the redemption date was extended until July 20th. ${ }^{52}$ These and other heavy debts owed to The Ammonia Corporation would remain on the books. This state of affairs arose from the precariousness of Niagara Ammonia's situation in 1926. It was facing heavy losses, apart from those arising out of substantial cuts in the price of anhydrous ammonia. For various reasons, the daily output target could not be met. Though there were plans to enter into the nitrogen fertilizer business at Niagara Ammonia, the facility was too small to compete with the major producers of nitrogen products for agriculture. As with the operators of FNRL units, the scale of working with electrolytic hydrogen was both limiting and expensive. By 1926, the main investors had sunk well over half a million dollars into the venture and had seen no return. Debts were mounting up, and, with the reduced price of ammonia, a turn to profitability did not seem likely. Investors must have been wary of injecting additional funds into an enterprise that was confronting several challenges, including from a new, and powerful, player in the industry.

\section{DU PONT AMMONIA}

Du Pont's interest in synthetic ammonia was revived early in 1923, following somewhat exaggerated claims concerning the Claude process made by a representative of Air Liquide to Du Pont's Norwegian born and German trained Fin Sparre, director of the Development Department, and head of much of the corporation's diversification programme. Sparre had previously been against embarking on manufacture of synthetic ammonia, though he expressed a strong interest in oxidation of ammonia to nitric acid. What impressed him now was the high yield achieved at pressures far greater than used in the process of Allied Chemical, possibly sufficient to make the latter obsolete, and the potential of catalyzed high-pressure technology. ${ }^{53}$ Samuel K. Varnes of Du Pont, writing in 1947, observed that when in October 1923 a Du Pont commission travelled to Monterau, France, to investigate Claude's pilot plant they were somewhat disappointed. ${ }^{54}$ Claude advised Du Pont that his process was not yet fully developed. The first steel converters were incapable of withstanding the severe operating conditions. By 1924, major improvements had been made, with the introduction of special alloys for the converters. As a result, in the summer of 1924, Du Pont acquired exclusive US rights to the Claude process from Air Liquide. ${ }^{55}$ To formulate a nationwide marketing programme, Du Pont also acquired National Ammonia, the major US distributor of ammonia for refrigeration purposes. Du Pont now prepared to repeat its success with organic chemicals in the area of nitrogen products.

Du Pont's stated original intention was to enter the market for ammonia as refrigerant, distributed through National Ammonia, and later move into oxidation of ammonia, to nitric acid, and production of nitrogen fertilizers. National Ammonia would thereby begin to play a new role in the nitrogen distribution business. On 21 May 1925, jointly with Air Liquide, Du Pont incorporated in West Virginia the firm Lazote, Inc. Air Liquide provided 25 per cent of the capital in this partnership. Fin Sparre was appointed president of Lazote. Construction work began on an ammonia factory at Belle, East Kanawha County. Soon after, Du Pont announced that Georges Claude had on 30 June 1925 received letters patent 1544373, assigned to Lazote, "covering broadly a method of conducting the synthetic operation wherein the pressure-sustaining wall is cooled by the incoming gases which are preheated by heat exchange with outgoing gases from the zone of reaction." Tellingly, "Lazote, Inc., is prepared to enforce its rights under this patent and prevent infringement thereof." ${ }^{56}$ 
A catalyst testing laboratory, under the supervision of chemical director Roger Williams, and modelled after that of the FNRL, was installed at Du Pont's Wilmington Experimental Station. Alfred Larson, as noted previously at the FNRL, conducted further investigations at Wilmington. The Belle facility, where hydrogen was produced from water gas, and nitrogen from producer gas (blow-run gas, or blow gas), both made from coke, opened on 1 April 1926. Du Pont announced that it was represented by its distributor, the National Ammonia Company..$^{57}$

The Claude process did not come up to expectations. ${ }^{58}$ There were problems with the high-pressure, or hyper-, compressors ("hypers"), water gas and gas purification equipment, liquefaction plant, and converters. ${ }^{59}$ The rated capacity, of 20-tpd, was difficult to achieve. Aware of the difficulties, and dangers, including explosions and casualties, Du Pont began to take an interest in the Casale process, no doubt in part because, having invested in hypercompressors, it wished to continue working with pressures way beyond those used in other synthetic ammonia processes (all of which $\mathrm{Du}$ Pont intended to outperform). Apart from these considerations, Casale's process was still the only independent, well-tried process suited to large scale production available for licensing in the United States in 1926 (the German Mont Cenis and the Nitrogen Engineering Corporation processes were new, and the Italian Fauser process was in the hands of Montecatini, which had only just started to consider licensing arrangements). While access to Casale's process could have been obtained through a licensing agreement with The Ammonia Corporation, Du Pont chose another way, acquisition of the Casale ammonia patents in the United States.

\section{CHALLENGING THE CASALE PATENTS}

The way to capture the superior Casale technology was to engage in litigation based on a patent suit, in which it would be argued that the Casale patents infringed certain of Claude ammonia patents. This would bring about the downfall of existing interests in the Casale process in the United States and open the way for Du Pont's acquisition of Casale technology. In 1926, Lazote commenced proceedings against The Ammonia Corporation and Niagara Ammonia, in Buffalo, New York State, for patent infringement. Because the claims in the United States for both processes were construed as broad, the wording of certain of the Casale patents were open to attack. This mainly concerned the very high pressure, considerably greater than that of the Haber-
Bosch process, which was a feature common to both the Casale and Claude processes. Du Pont, through Lazote, pushed for an injunction against Niagara Ammonia's operations, in addition to claiming damages. ${ }^{60}$

Niagara Ammonia, totally reliant on Casale technology, prepared to be tested in litigation. The company, facing difficulties, financial as well as operational, and unable to achieve its intended output of ammonia, was a weak contestant. Though no account of the proceedings appear to have survived, it is apparent that the indictment offensive engineered by Du Pont's high powered patent lawyers was sufficient to topple the defence. Matters were brought to a head during the last week of May 1927. The outcome was an out of court settlement, at a closed-door meeting, in the favour of Du Pont. ${ }^{61}$ In view of the parlous state of affairs at Niagara Ammonia, what Du Pont offered may even have appealed to some of those associated with the Casale enterprises. The arrangement enabled Du Pont to aquire all rights to the Casale patents in the United States.

Du Pont, by injection of capital, also took over control of Niagara Ammonia, The Ammonia Corporation, and Electro-Chemical. A Du Pont press release from the Publicity Bureau revealed only the acquisition of patent rights from The Ammonia Corporation. ${ }^{62} \mathrm{~A}$ boardroom reshuffle at Niagara Ammonia took place on 27 May 1927, at a meeting held in New York, followed on the same day by decisions on certain manufacturing operations at Niagara Falls. Pierce, the president, and the other Niagara Ammonia directors resigned. Du Pont senior people were installed in their places, with F. S. MacGregor as president, and W. S. Gregg as vice president. ${ }^{63}$ As for The Ammonia Corporation, Pierce and his co-directors were summarily ousted, and replaced by $\mathrm{Du}$ Pont men, with MacGregor as president. ${ }^{64}$ The changes were soon known in the trade. In May 1927, Herbert Humphrey of Britain's ICI ammonia facility at Billingham was on a fact finding mission in the United States, and was informed of the fate of Ammonia Casale interests. ${ }^{65}$ By 6 June 1927, the day the transfer of patent rights was announced in the Oil, Drug and Paint Reporter, Du Pont was in possession of all stock in Niagara Ammonia. ${ }^{66}$ This included Electric Bond \& Share's former substantial interest, as held in the name of Frank Smiley. Arrangements began for the transfer of Ammonia Casale stock in Hydro-Electric to Du Pont. ${ }^{67}$ MacGregor, Niagara Ammonia's new president, replaced Pierce as president of Hydro-Electric.

On the occasion of the May 27 shakeout, MacGregor recommended sale of the electrolytic plant, including the Electrolabs cells. Latterly (and perhaps for some time) the plant had relied on hydrogen purchased from Hook- 
er. ${ }^{68}$ (The Electrolabs cells remained in place, unused, until moved to Seattle in 1928; see later.) Undoubtedly, the high cost of hydrogen was a major contributor to the losses at Niagara Ammonia. The Niagara Ammonia factory ceased operating in July 1927.69

$\mathrm{Du}$ Pont made further share transfers and continued to reshuffle the boards. On 3 October 1927, Ammonia Casale's stock of 2,125 shares in Hydro-Electric were transferred to Du Pont, and, in turn, on 22 December 1927 they were transferred from Du Pont to Lazote (Table 3). Du Pont people elected to the board of HydroElectric were Jasper E. Crane (member of the executive committee responsible for international affairs, and vice president of Du Pont from 1929), and engineer Frederick A. Wardenburg. ${ }^{70}$ On 30 December 1927, Du Pont transferred its stockholdings in the Hydro-Electric Chemical Company, the Phosphorus-Hydrogen Company, and the Chemical Investment Corporation, to Lazote. Crane was appointed chairman of the board of directors of Lazote Inc., and Wardenburg, until then vice president, was appointed president, replacing Fin Sparre.

On 26 January 1928, at a meeting held in the Du Pont Building, Wilmington, presided over by MacGregor, the voluntary petition in bankruptcy of the Niagara Ammonia Company was sanctioned..$^{71}$ On the same day, the directors of The Ammonia Corporation met at its offices in New York. Of the seven directors present, six agreed that because the corporation was unable to pay its debts (as a result of the failure of Niagara Ammonia) it was necessary to declare the corporation bankrupt. ${ }^{72}$ MacGregor, as president of both Niagara Ammonia and The Ammonia Corporation, filed voluntary petitions in bankruptcy. The New York Times reported that the liabilities of Niagara Ammonia were $\$ 947,748$, and assets $\$ 107,899$. The principal creditor was The Ammonia Corporation, with liabilities of $\$ 839,249$, and assets of $\$ 498,467$. The corporation was indebted to Lazote for the sum of $\$ 821,714$. The principal listed assets of the corporation were rights to "foreign" patents, namely those relating to the Casale synthetic ammonia process, valued at $\$ 350,000$ (this sum probably included the Phosphorus-Hydrogen Company's patents). These valuable patents were now in the hands of Lazote. Plant, stock and fixtures of Niagara Ammonia were valued at $\$ 97,579$, which in the newspaper report were assigned to The Ammonia Corporation, as creditor. ${ }^{73}$ It had been an expensive business all round, but now, at least, Lazote was firmly in control of the Casale ammonia process, and the useful Italian-made high-pressure converters and equipment of Niagara Ammonia. The Ammonia Corporation and Niagara Ammonia, together Ammonia Casale's sole overseas venture, were laid to rest.
Du Pont immediately introduced the Casale ammonia process at the Belle Lazote facility. As a first step, the converters and machinery from the defunct Niagara Ammonia factory were shipped to Belle. Over the winter

Table 3. Holdings in common stock, Hydro-Electric Chemical Company, probably late 1927.

Bonn \& Co., Inc. 980 (assigned 1923)

Jasper E. Crane 1

Luigi Casale 1 (deceased February 1927)

Chemical Investment Corporation, Wilmington, 10,191 (assigned 1923)

Lazote, Inc., 7,840 (originally assigned to Ammonia Casale, 1923)

Charles J. Hardy 490 (assigned 1923)

Ernest Iselin 1

G. A. Henrie 1

Josiah T. Newcomb 50 (assigned 1923)

Henry J. Pierce $200+200$ (assigned 1923)

Walter U. Reisinger 1

Samuel K. Varnes 1

David Barker Rushmore 40 (assigned 1923)

Roger Williams 1

M. L. Farrell 1

F. A. Wardenburg 1

Total 20,000

Source: Undated typewritten list, "Stockholders - Hydro-Electric Chemical Company." Added, in hand, holders of preferred stock were listed as Bonn \& Co. (250 shares), Lazote, Inc. (2,125 shares, from Ammonia Casale SA, also referred to as Casale Ammonia Co.), Chemical Investment Corporation $(5,000)$, and Charles J. Hardy (120). Hydro-Electric Chemical Co., Stock certificate book, 1923-28. Records of E. I. Du Pont de Nemours \& Co. Absorbed companies. Hagley Museum and Library, Wilmington, Delaware, Accession 500, box 848.

The authorised capital of Hydro-Electric was $\$ 750,000$, with 20,000 shares non par. Casale Ammonia Co. (Ammonia Casale SA) in 1923 held 2,125 preferred, and 7,840 common stock in HydroElectric. The 2,125 preferred shares were transferred to Du Pont on 3 October 1927, and then to Lazote on 22 December 1927. The Chemical Investment Corporation, the holding company for Hydro-Electric, held 5,000 preferred stock, out of a total of 7,500 (later increased to 9,000), and 10,191 common stock. The Bonn \& Co. holdings were transferred to Lazote on 28 February 1929. Apart from Ammonia Casale, Chemical Investment Corporation, and Bonn \& Co., early investors were Charles J. Hardy, Henry J. Pierce, and David B. Rushmore.

Hydro-Electric directors in 1924: Henry J. Pierce (president), Clement R. Ford, A. E. Bonn, René Leprestre, Ernest Iselin, Charles J. Hardy, George S. Baker (resigned September 1925; M. L. Farrell became director in his place), George H. Howard, Frank McCommon. Hydro-Electric directors in May 1925: Henry J. Pierce (president), Clement R. Ford, R. L. Farrell, Ernest Iselin, J. W. Mooney, Luigi Casale, George H. Howard, Frank McCommon, Frank E. Southard. Southard, of Augusta, Maine, was a lawyer representing utility interests, probably including Electric Bond \& Share. HydroElectric Chemical Co. Directors \& Stockholders Minutes, 1924-26. Records of E. I. Du Pont de Nemours \& Co. Absorbed companies. Hagley Museum and Library, Wilmington, Delaware, Accession 500 , box 847 . 
of 1927-1928, Du Pont authorised three-fold expansion in output of synthetic ammonia, based on the introduction of the Casale process. New Casale-type converters were ordered for installation in a designated building. ${ }^{74}$ By this time, Casale converters of 20 -ton daily rated capacity were in general use.

Hydro-Electric was retained as a Du Pont subsidiary, probably in the hope that the phosphorus-hydrogen process, or other electrochemical processes might become viable. Lazote's arrangements with Casale interests presumably included access to a new feature, the ejector, a static piece of equipment which did away with the need for a gas circulation pump, as developed by Luigi Casale at Terni. This was an important consideration since reciprocating pumps and compressors working under the high pressure conditions required frequent attention, and there were always concerns over contamination of gas mixtures with lubricating oils.

\section{DIVERSIFICATION AT BELLE}

The success with ammonia encouraged Roger Williams to develop a high-pressure methanol process, using the same converters as employed in the ammonia synthesis. Methanol production was expanded greatly from around 1928. It was used in the production of formaldehyde (for Bakelite), antifreeze, and other large volume products. Significantly, by 1928 American inventors had developed four of the eight synthetic ammonia processes in use (General Chemical/Allied Chemical, Du Pont, FNRL, and NEC). However, it was Du Pont's entry into high-pressure chemistry that stimulated the development of more general high-pressure chemical production.

Technology transfer from Europe to $\mathrm{Du}$ Pont in the area of ammonia production included a contribution from Britain's ICI. At the end of the 1920s, ICI and Du Pont drew up an agreement for exchange of knowhow. ICI (into which Brunner, Mond had been merged in 1926) had an interest in Allied Chemical, through Solvay Process, and the agreement was strongly opposed by Orlando Weber. In November 1928, ICI severed its ties with Allied Chemical. Soon after, Du Pont representatives inspected the ICI Billingham ammonia factory. While much was learned, it was perhaps not readily applicable to the high-pressure processes at Belle. Probably of great interest were the water gas process for manufacture of hydrogen, which closely followed German technology, as copied from BASF, oxidation of ammonia to nitric acid, control instruments, and perhaps ICI's then early work on steam reforming of hydrocarbons for manufacture of hydrogen.
In 1929, following the increased reliance on Casale technology, Du Pont bought out Air Liquide's holdings in Lazote, a strategy that was adopted in other cases of joint ventures with European companies. ${ }^{75} \mathrm{Du}$ Pont's ammonia interests became the Du Pont Ammonia Corporation. By September 1929, expansion at Belle brought the rated daily capacity of ammonia to over 220 tons. In around 1930, the daily capacity at Belle was $100 \mathrm{tpd}$ of ammonia by the Casale process, and 125-tpd by the Claude process. ${ }^{76}$

Reminiscences of managers and staff at Belle show that for a few years the Claude and Casale processes were confined to separate production areas; and the main early increase in production was due to the introduction of Casale technology. ${ }^{77}$ The Du Pont synthetic ammonia process, through innovations adopted from the Casale process, had become the modified process of Du Pont. ${ }^{78}$ Contemporary accounts, including by $\mathrm{Du}$ Pont personnel, speak of the excellence of Du Pont's ammonia process. The process, it was noted, "has decidedly new and advantageous features and represents a radical departure from the original Claude process." 79 Jasper Crane, writing in 1933, stated that the "best features" of the French and Italian processes "were adapted to ... American conditions." ${ }^{80}$ One author even referred to the "modified Casale process operated by Du Pont."

In 1931, the assets of the Du Pont Ammonia Corporation were transferred to the new Ammonia Department, with Wardenburg as general manager. National Ammonia remained a separate Du Pont company, working closely with the Ammonia Department. ${ }^{82}$ Further expansion at Belle during the early 1930s brought the annual rated capacity of synthetic ammonia to around 145,000 tons. Ammonia was converted into ammonium sulphate fertilizer, nitric acid, and other industrial products. A Sales Development Division investigated new uses for the ammonia. The location of the Belle facility, in the lower Kanawha Valley, well inland, and protected, was used to emphasise the strategic value of the site for purposes of producing nitrogen products important to the national defence.

Contrary to the early expectations at Du Pont, its very high-pressure process did not make the Allied Chemical (General Chemical) and similar processes carried out below 300 atmospheres obsolete. By the mid-1930s, Allied Chemical was responsible for $60 \%$, and Du Pont for $40 \%$, of synthetic ammonia produced in the United States. They collaborated in control of the fertilizer market, partly through Allied Chemical's Barrett Division, as distributor of ammonium sulphate. One important outcome of the availability of inexpensive synthetic ammonia was that during the 1930s 
it almost completely replaced Chilean nitrate as the source of the world supply of nitric acid. Anhydrous ammonia, from all sources, continued to be largely used as a refrigerant, though consumption relative to synthetic ammonia for fertilizer use was not great. National Ammonia remained Du Pont's distributor of anhydrous ammonia.

\section{DU PONT INNOVATIONS}

The Wilmington-based Du Pont was, for long periods of its history in the 20th century, the most innovative chemical company in North America. During and after World War I it became one of the leaders in aromatic organic chemistry, enabling massive expansion during the 1920s in the manufacture of synthetic dyestuffs and modern explosives. In dyes and other sectors Du Pont relied on its capabilities as a prolific dealmaker, particularly for access to new technologies. This is reflected in the long list of strategic acquisitions made by the corporation as held at the Hagley Museum and Library. How, and under what circumstances, those acquisitions were made, and for what reasons, varied according to the perceived needs of the corporation. In the case of ammonia, as this article has demonstrated, it was the failure of the expensive Claude technology, but the commitment to high-pressure chemistry, that was the stimulus for acquisition of the Casale technology that operated over a similar pressure range. Niagara Ammonia, The Ammonia Corporation, and the HydroElectric Chemical Company, are just three entries in the portfolio that direct historians to folders on absorbed companies. These Casale enterprises contributed to the great success with catalytic high-pressure chemistry achieved by 1930 .

The lessons taken from this small but highly instructive episode relate to the balance of power between weak firms or start-ups with a useful technology and large corporations desperate to gain access to that technology. By delving deeply into the archival records, much about how and why has been revealed, directly and indirectly, concerning Du Pont's motives and actions for entering into a new area of the nitrogen industry. Above all, the fine detail of these acquisitions reveals far more than the overlapping stories of one struggling start-up and the initial failure of a major corporation when embarking on a completely new area of diversification. It concerns what was genuinely an important, and eventually highly successful, phase in Du Pont's interwar entry into a new sector of heavy chemical industry.
This provided a novel context for innovation, and, I argue, probably the key to one of the most profound transformations at Du Pont, ensuring that the corporation remained relevant in commercialization of new discoveries for decades to come. Though synthetic ammonia was certainly low in the list of Du Pont innovations, and at first hardly met the criteria for investment, it had a tremendous impact on the long term standing of a technology giant. Early on, research and development for new products based on high-pressure processes enabled Du Pont to alleviate the difficulties confronted by the loss-making Ammonia Department. ${ }^{83}$ This helped to propel the corporation to first place as the leading innovative chemical firm in the United States, drawing on catalytic high-pressure technologies for industrial production of a proliferation of new of products, notably nylon, followed by other polymers, and later even broader diversification. ${ }^{84}$ From 1930, there was also, from a different direction, the first chlorofluorocarbon (CFC) cooling refrigerant, Freon, commercialized by Du Pont, following research at General Electric. It was adopted for air conditioning, and later household refrigeration; in several uses it replaced sulphur dioxide and ammonia. ${ }^{85}$

Du Pont's expertise in ammonia technology, drawing on its acquisition of the Casale process, contributed to American preparedness for war after the government decided to construct ammonia factories for munitions production. Du Pont built the first government-owned contractor-operated facility, completed in 1941, at the Morgantown Ordnance Works, Monongalia County, West Virginia, with a capacity of 180,000 tons of nitrogen per year.

\section{Du Pont, Pacific Nitrogen, and Roessler \& Hasslacher Co.}

For sake of completeness, it is worth including a brief account of Du Pont's two other acquisitions in early synthetic ammonia businesses, one on the west coast and the other on the east coast. The west coast venture, which we have already met, was the Pacific Nitrogen Corporation, of Pacific Ammonia, the affilitate of National Ammonia, in Seattle, Washington. Pacific Nitrogen, was incorporated in 1924. Its entire stock was acquired by Du Pont in 1927.

Pacific Nitrogen used the FNRL process to produce both anhydrous ammonia and ammonia liquor. In May and June 1928, the Seattle plant produced 2.98 tons of ammonia every 24 -hour hours, in accord with the daily capacity of its single FNRL unit. ${ }^{86}$ In April 1928, Pacific Nitrogen was authorised to receive the electrolytic cells of Niagara Ammonia: "App[ropriation]n \$35,000.00 Purchase and installation of 170 electrolytic cells owned 
by Lazote, Inc., and at present at the plant of the Niagara Ammonia Company, Niagara Falls, New York" (capitals in the original). ${ }^{87}$ Their installation in Seattle was completed in July 1928. Caustic potash for charging the cells was due to arrive on July 22nd, "and it is anticipated that the cell installation will be ready for trial operation the latter part of August." On 31 December 1930, the Du Pont Ammonia Corporation, as owner of the stock of Pacific Nitrogen, arranged to take over its assets and property. ${ }^{88}$ The Pacific Nitrogen factory, the last in the United States to use dedicated electrolysis cells for hydrogen in manufacture of ammonia, was closed down in the early 1930 s. $^{89}$

The east coast synthetic ammonia business was that of Roessler \& Hasslacher Co., of Niagara Falls, where production based on a modified FNRL process, also at a rated capacity of 3-tpd, began in 1926. For synthetic ammonia, it relied on in-house by-product hydrogen from electrolytic manufacture of sodium, and, from 1928 , by-product hydrogen piped to the factory from Hooker Electrochemical. ${ }^{90}$ In 1928 the ammonia capacity of the facility was raised to nine tons daily. Uses included in the manufacture of sodium cyanide, as well as for general sale. In 1930, Du Pont acquired Roessler \& Hasslacher Co.; in 1932 it became the R\&H Division of Du Pont (and later the Electrochemicals Division).

\section{CONCLUSION}

Late in 1927, the leading American journal of industrial chemistry, Industrial and Engineering Chemistry, reported that "A belated start in the fixation of atmospheric nitrogen seems to have been overcome by the development of our own processes-so satisfactory as to more than hold their own in world competition." ${ }^{\text {1 }}$ The turning point in the establishment of a competitive American synthetic ammonia industry would be achieved from late 1928. Until then, production in the United States was on a small scale, and mainly for the refrigeration market. This, however, demanded purer ammonia than was at first available, as we have seen at Allied Chemical and Niagara Ammonia. Significantly, Allied Chemical's Syracuse facility, the first to operate with any degree of success, served mainly as an experimental facility. The same was true elsewhere, including at Du Pont, even if not intended. Du Pont, suffering from problems with the Claude process, had to look elsewhere. During 1926-1927, Du Pont resorted to patent litigation against a weaker rival, the group of financially troubled Casale-related firms, to gain access to the latter's process patents. Du Pont, after having acquired its intended trophy, as well as Casale equipment, quickly dismembered and bankrupted Niagara Ammonia and The Ammonia Corporation, and embarked on nitrogen fertilizer and nitric acid production, both starting with synthetic ammonia.

From late 1928, five years after success in Europe and Japan, and partly through changing economic conditions, the US synthetic ammonia industry began to stand its ground in production for the fertilizer market. Du Pont and Allied Chemical were the main producers; their competitive advantages arose from the large scales of production. However, not long before the Wall Street Crash the exuberance of the late 1920s was already being tested by the threat of global overproduction and overinvestment in nitrogen fertilizers. During 1929-1932, cutbacks were substantial. However, when recovery and renewed diversification began, there was an atmosphere of free and uninhibited innovation and extraordinary growth in the American chemical industry, especially at $\mathrm{Du}$ Pont. Synthetic nitrogen fertilizers and catalytic high-pressure processes, including for methanol, higher alcohols, and the spinoffs from research into synthetic gasoline, were at the forefront, stimulated by the examples of rivals in Europe. The new triumph of American high-pressure chemistry enabled innovations that became bargaining tools in dealing with foreign manufacturers. The export of Du Pont and NEC ammonia technologies and know how brought in considerable revenue. A decade on, in the mid-1940s, the US synthetic ammonia industry, following massive expansion for munitions purposes during World War II, had become a world leader, and was still growing.

Within the larger context of the growth and expansion of the American chemical industry, the ammonia sector represented one of the main areas in which diversification relied on the adoption of European technologies and acquisition of firms that offered novel product lines. ${ }^{92}$ In this, $\mathrm{Du}$ Pont moved from the manufacture of dyes and intermediates, through inhouse research, and then into high pressures and synthetic nitrogen and related products. However, the delayed entry into the latter was in part due to the already high investment in imported nitrates that were necessary for production of nitric acid used in synthetic dye and explosives production. Once success had been achieved in synthetic ammonia at Du Pont, following acquisition of Niagara Ammonia, and the Casale patents, the conversion of ammonia by oxidation into nitric acid was a logical next step, as was invention of a synthetic methanol process, and conversion of ammonia into urea. This was the prelude to Du Pont's rise to first place among innovative American firms, particularly in the mid-1930s, with manufacture of 
nylon, which relied on synthetic ammonia. Allied Chemical may have been less innovative, but, significantly, sacrificed synthetic organic chemistry in order to enhance its role in ammonia production, with, from the late 1920s, an emphasis on nitrogen fertilizer production. In nitrogen products, there were strong parallels elsewhere, most particularly at the American Cyanamid Company which during World War I had converted its calcium cyanamide, based on a German process, and originally produced as a fertilizer, into ammonia for the manufacture of explosives, and of urea for Du Pont. The ammonia was oxidised in German-made plant, imported just before the war. American Cyanamid, however, moved into synthetic dyes later than Du Pont, with the acquisition in 1927 of the Calco Chemical Company, itself a merger of firms engaged in dyes and pigments. ${ }^{93} \mathrm{In}$ 1930, American Cyanamid entered into synthetic ammonia and methanol through acquisition of the Chemical Construction Company (Chemico) that had acquired the Nitrogen Engineering Corporation and its synthetic ammonia process. Chemico's synthetic ammonia process, like that of Du Pont, was soon after licensed to several European firms. From the 1930s, transatlantic technology transfer of high pressure and many other chemical processes, including for nitric acid, was just as likely to be from America to Europe (and elsewhere) as it was from Europe to America.

\section{ACKNOWLEDGEMENTS}

The two reviewers are thanked for their extremely constructive criticisms. Special thanks to the staff at Hagley Museum and Library, Wilmington, Delaware; the Othmer Library, Science History Institute, Philadelphia, Pennsylvania; and the Sidney M. Edelstein Library, the National Library of Israel, Jerusalem, Israel.

\section{REFERENCES AND NOTES}

1. K. Steen, The American Synthetic Organic Chemicals Industry: War and Politics, 1910-1930. The University of North Carolina Press, Chapel Hill, 2014.

2. D. A. Hounshell, J. K. Smith Jr, Science and Corporate Strategy. Du Pont $R$ and D, 1902-1980. Cambridge University Press, Cambridge, 1988, pp. 183-189.

3. A. S. Travis, Nitrogen Capture: The Growth of an International Industry (1900-1940). Springer, Cham, 2018.

4. Hounshell and Smith, Science and Corporate Strategy, pp. 183-189; P. A. Ndiaye, Nylon and the Bomb:
DuPont and the March of Modern America (transl. Elborg Forster) The Johns Hopkins University Press, Baltimore, 2007, pp. 74-81. That little had appeared on developments in the Claude process is indicated in W. H. Shearon, H. L. Thompson, Ammonia at 1000 Atmospheres, Chem. Ind. Eng., 1952, 44(2), 254-264, on 260.

5. G. Bruni, Luigi Casale, Giornale di chimica industrial ed appplicata, 1927, 9(2), 90.

6. J. B. Lipman, Fertilizer Prospects for 1926: The Use of Concentrated Fertilizer Materials in Potato Fertilization, American Potato Journal, 1926, 3(1), 3-9, on 4.

7. O. Wilson, Gases in Commerce and Industry, Ind. Eng. Chem., 1926, 18(12), 1273-1276, on 1276.

8. On dangers associated with early refrigeration, see J. Rees, 'I Did Not Know... Any Danger was Attached.' Safety Consciouseness in the Early Ice and Refrigeration Industries, Technology and Culture, 2005, 46(3), 541-560. See also H. Peavitt, Refrigerator: The Story of Cool in the Kitchen. Reaktion Books/Science Museum, London, 2017.

9. M. J. Clarke, The Federal Government and the Fixed Nitrogen Industry 1915-1926. PhD dissertation, Oregon State University, 1976.

10. Following the 1921 suspension of the Nitrate Division, administration was transferred to the Department of Agriculture. In 1926, the FNRL was absorbed into the laboratories of the Bureau of Soils.

11. Clarke, The Federal Government, pp. 158-160.

12. Synthetic Ammonia, Ind. Eng. Chem., 1925, 17(8), 772.

13. Travis, Nitrogen Capture, pp. 227-245, 330-334.

14. Luigi Casale US patent 1348428 of 12 July 1921 (burning of air; process for generating from air and hydrogen, either nitrogen and hydrogen mixtures or nitrogen; filed 7 July 1920); and 1408987 of 7 March 1922 (catalytic apparatus for the synthesis of ammonia; filed 7 October 1920). See also patents 1447123 ("self making of ammonia"), 27 February 1923; 1478549 (catalytic apparatus for the synthesis of ammonia) and 1478550, both of 25 December 1923. On 28 July 1925, Casale was granted patent 1547362, for electrolysis of water (filed 19 July 1922).

15. For the Electric Bond \& Share Company, see T. P. Hughes, Networks of Power: Electrification in Western Society, 1880-1930. Johns Hopkins University Press, Baltimore, 1983, pp. 392-401. In 1925, the Electric Bond \& Share Company was absorbed into the Electric Bond \& Share Securities Corporation, as holding company for General Electric.

16. Previously, Pierce had been president of the Wood Products Company (1885-1905), before taking up an 
interest in railroads. Henry J. Pierce Dies; Utilities Official, New York Times, 10 August 1947, p. 10.

17. D. B. Rushmore, E. A. Lof, Hydro-Electric Power Stations. John Wiley \& Sons, New York, 1923 (first edition 1917).

18. Clarke, The Federal Government, pp. 77-107, 122123.

19. No. 77, Nitrogen prod. Synth amm. Haber proc. catalysts. Analysis of samples received from Germany between February and August 1919. H. E. Jones, Brunner, Mond \& Co., Northwich, February-August 1919; and No. 78, Nitrogen prod. Synth amm. Haber proc. catalysts and catalysers. Examination of Oppau catalysts from vanadium. H. E. Jones, Brunner, Mond \& Co., Northwich, May 1920. Solvay Process Company archives, microfilm reel 2, the Sidney M. Edelstein Library, National Library of Israel, Jerusalem.

20. K. Bertrams, The Making of International Alliances. In Solvay: History of a Multinational Family Firm (Eds.: K. Bertrams, N. Coupain, E. Homburg) Cambridge University Press, Cambridge, 2013, pp. 193228, on 199-202.

21. American Chemical Society Favors Selective Embargo, Oil, Paint and Drug Reporter, 12 September 1921, p. 23.

22. B. Waeser, The Atmospheric Nitrogen Industry: with Special Consideration of the Production of Ammonia and Nitric Acid (transl. E. Fyleman) P. Blakiston's Son \& Co., Philadelphia, 1926, p. 287. This was a translation of B. Waeser, Die Luftstickstoff-Industrie mit Besonderer Berücksichtigung der Gewinnung von Ammoniak und Salpetersäure. Springer-Verlag, Berlin, 1922. E. Fyleman, was chief chemist at the Crowley \& Partners engineering consultancy in London that represented the Casale ammonia process in the United Kingdom.

23. W. Haynes, American Chemical Industry: A History, vol. II. The World War I Period: 1912-1922. D. Van Nostrand, New York, 1945, p. 122; F. A. Ernst, Fixation of Atmospheric Nitrogen. Chapman \& Hall, Ltd., London, 1928, pp. 131-132.

24. Steen, American Synthetic Organic Chemicals, p. 254.

25. For a number of years it served "as an experimental plant to explore markets and develop technical information and operating experience" that was put to use at Hopewell. Williams Haynes, American Chemical Industry: A History. vol. VI. The Chemical Companies. D. Van Nostrand, New York, 1949, p. 394.

26. R. E. Welch, Solvay Process Among State's Mightiest Plants, Syracuse Journal, 28 July 1934, p. 8.

27. Hydro-Electric Chemical Co. and Frederick Pope were among holders of preferred stock in The
Ammonia Corporation. The Ammonia Corporation, A Preferred Stock, box 66; and The Ammonia Corporation, Directors \& Stockholders minutes 1926-28, box 67. Records of E. I. Du Pont de Nemours \& Co. Absorbed companies. Hagley Museum and Library, Wilmington, Delaware (hereafter: Hagley), Accession 500, series II, part 1 (hereafter: Ammonia Corporation); and Hagley, Hydro-Electric Chemical Co. Stock Certificates, 1923-28, Accession 500, series II, part 1, box 848 (hereafter: Hydro-Electric Stock). See also list of stockholders, in H. J. Pierce to Hydro-Electric Chemical Co., New York, 1 August 1923. Hagley, Hydro-Electric Chemical Co. Directors \& Stockholders Minutes, 1924-26, Accession 500, series II, part 1, box 847 (hereafter: Hydro-Electric).

28. Frederick Pope, Engineer Dead. Set up Synthetic Ammonia Plants Here and Abroad, New York Times, 13 August 1961, p. 88.

29. F. Pope, Condition of Chemical Plants in Germany, Ind. Eng. Chem., 1919, 11(6), 512.

30. T. W. Sill, The Dyestuff Plants and Their War Activities, Ind. Eng. Chem., 1919, 11(6), 509-512.

31. R. Thomas, Salt \& Water, Power and People. A Short History of the Hooker Electrochemical Company. Hooker Electrochemical Company, Niagara Falls, 1955, p. 47.

32. Two proposals for sale of oxygen from the Electrolabs cells were considered: one for sale to the International Oxygen Company; the other for the formation of a joint marketing company with Electrolabs.

33. Steen, American Synthetic Organic Chemicals.

34. Regular monthly meeting of the directors of the Niagara Ammonia Company, 14 November 1923, Niagara Ammonia Co., Inc. Directors \& Stockholders Minutes, 1923-26. Hagley, Accession 500, Series II, part 1, box 1366 (hereafter: Niagara Ammonia). See also Haynes, The World War I Period, pp. 503, 504.

35. Regular monthly meeting of the directors, 21 December 1923, Niagara Ammonia.

36. L. Cerruti, La fissazione dell'azoto, ovvero l'ambiguità della scienza, 5-6. http://www.minerva.unito.it/ storia/chimicaclassica/azoto/azoto4.htm (accessed 20 December 2020)

37. Haynes, Chemical Companies, p. 394.

38. Minutes of meeting of board of directors, 30 July 1924, Niagara Ammonia.

39. Minutes of the board of directors, 30 July 1924 . With attachments: D. T. Kiley, Armour Co., Chicago, Ill, to A. E. Bonn, Niagara Ammonia, 30 July 1924; and J. R. Powell to Kiley, 24 July 1924, Niagara Ammonia.

40. Minutes of the board of directors, 30 July 1924, Niagara Ammonia. 
41. A. Miolati, Synthetic Ammonia and the Casale Process. Amplified edition of a lecture delivered the $27^{\text {th }}$ February 1927 at the Institute of Chemistry of the Polytechnic School of Prague (transl. G. Impallomeni, 2009) "L'Universale" Tipografia Poliglotta/Ammonia Casale SA, Rome, 1927, p. 34.

42. Meeting of the board of directors, 14 November 1924. It was resolved, as at that date, that the offices be moved from 280 Madison Avenue to 65 Broadway, Niagara Ammonia.

43. Stockholders were: Hooker Electro-Chemical Co., common stock, 250; The Ammonia Corporation, A preferred, 3,983 1/3, common, 889 1/6; and Frank L. Smiley, A preferred, 1,016 2/3, common, 260 5/6. Total A preferred stock 5,000; total common stock 1,400. Annual stockholders meeting, 2 February 1925, Niagara Ammonia.

44. Pope was also a broker, and later sold (what probably included his own) holdings in The Ammonia Corporation. Note of sale of 350 preferred (at \$100) and 652 2/3 common (at \$25) stock from Pope \& Company, 60 Broadway, New York, to Tucker, Anthony \& Co., 120 Broadway, New York, 22 September 1925, Ammonia Corporation, box 67.

45. Frederick Pope, Envoy Needed in Russia, New York Herald, 14 November 1932.

46. A. C. Sutton, Western Technology and Soviet Economic Development, 1930-1945. Hoover Institution, Stanford, 1971, pp. 99-100. The American chemical engineer Alcan Hirsch ostensibly demonstrated more enthusiasm for the Soviet system. Travis, Nitrogen Capture, pp. 316, 322-324.

47. Phosphorus-Hydrogen Company to Hydro-Electric Chemical Co., 21 April 1924, Hydro-Electric. See also, Thomas Edward Warren, The Dissociation Pressures of the Orthophosphates of Ammonia, research paper, McGill University, 1926. OAI identifier: oai:digitool.library.mcgill.ca:141772 (accessed 20 December 2020)

48. Meeting of the board of directors, 9 December 1925, Hydro-Electric.

49. A. M. Fairlie, Sulfuric Acid Manufacture. Reinhold Publishing Corporation, New York, 1936, pp. 150151.

50. Why Synthetic Ammonia Prices are Lower, Chemicals, 1926, 26(25), 12-13.

51. Meeting of the board of directors, 2 Rector Street, New York, 15 March 1926, Niagara Ammonia. The Ammonia Corporation was in turn indebted to the Irving Bank-Columbia Trust Company (formed, in 1923, when the Columbia Trust Company of New York merged with the Irving National Bank).
52. Meeting of the board of directors, 17 May 1926, Niagara Ammonia.

53. On Fin Sparre, see Hounshell and Smith, Science and Corporate Strategy, pp. 35-36, 37.

54. S. K. Varnes, Pioneering in High Pressure. In Sentimental History: The Du Pont Belle Works. A 75 Year History (Ed.: Charles J. Denham) Du Pont, Charleston, 2001, pp. 11-16, on 12 (from an account written in 1947).

55. Claude's first ammonia patent in the United States was no 1332460 of 2 March 1920. In 1921, he received a US patent for obtaining hydrogen from a gas mixture, and another for an apparatus suited to high pressure, high temperature exothermic reactions; in 1922, two patents for producing hydrogen and one for separating constituents in a gas mixture; in 1923, one patent for high pressure apparatus for production of ammonia, and one patent for a thermally insulated apparatus. Three of Claude's six US patents filed in 1924 covered the use of ammonia in production of ammonium chloride and sodium carbonate, which was relevant to the Solvay alkali process.

56. Claude Patent for a Method for Direct Synthesis of Ammonia, Ind. Eng. Chem., 1925, 17(9), 985. Claude's US ammonia patents were assigned to Lazote.

57. Glancing Back Over 1926, The Du Pont Magazine, 1927, 21(3), 1.

58. Varnes, Pioneering in High Pressure, p. 14.

59. Hounshell and Smith, Science and Corporate Strategy, pp. 183-189.

60. W. Haynes, American Chemical Industry: A History, vol. IV. The Merger Era. D. Van Nostrand, New York, 1948, p. 88. Meantime, National Ammonia Co. and Armour \& Co. in 1926 had taken out licenses for ammonia processes from the Chemical Foundation.

61. Haynes, The Merger Era, p. 88.

62. Du Pont Obtains American Rights on Casale Process, Chem. Met. Eng., 1927, 34(6), 388.

63. Board of directors. Meeting no. 29 (special meeting), 27 May 1927, Niagara Ammonia.

64. Following the death of Luigi Casale earlier in the year (on 18 February), his place was taken by Gregg, as vice president. Board of directors. Meeting no. 38 (special meeting), 27 May 1927, Ammonia Corporation, box 66.

65. Herbert Alfred Humphrey, Preliminary report on visit to United States of America. 9 April to 28 May 1927. Papers of Herbert Alfred Humphrey, Imperial College Archives and Corporate Records Unit, London, Item M6, pp. 94-97.

66. Du Pont Gets the U.S. Rights to Casale Patents, Oil, Paint and Drug Reporter, 6 June 1927, p. 21. E.I. du 
Pont de Nemours \& Co. held 1,116 2/3 of A preferred stock, and $3105 / 6$ of common stock; The Ammonia Corporation held 3,883 1/3 A preferred stock, and $8391 / 5$ of common stock (out of a total of 5,000 A preferred stock, and 1,150 common stock). Minutes of special meeting of stockholders, 6 June 1927, Niagara Ammonia.

67. Hydro-Electric Chemical Co., stock certificates, transfer documents, 10 June 1927. Including affidavits of Guiseppe Albisetti, member of the council of administration, Ammonia Casale SA, and Luigi Calissano, manager of Ammonia Casale SA, before the consulate of the United States of America, Milan, Italy. Hydro-Electric stock.

68. Ernst, Fixation of Atmospheric Nitrogen, pp. 121-123; B. Waeser, Die Luftstickstoff-Industrie, mit Berücksichtigung der chilenischen Industrie und des Kokereistickstoffs. Springer-Verlag, Berlin, 1932, pp. 163-164.

69. Haynes, The Chemical Companies, p. 213.

70. Du Pont, Wilmington, to Ernest Iselin, A. Iselin \& Company, 30 December 1927, Hydro-Electric.

71. Du Pont, Wilmington, letters regarding meeting to be held on 26 January 1928 to consider voluntary petition in bankruptcy of Niagara Ammonia Company, Inc., 19 January 1928, Niagara Ammonia. Ammonia Corporation, Board of directors, meeting no. 41 (Special meeting), 26 January 1928; board of directors, meeting no. 42 (special meeting), 10 March 1928, Ammonia Corporation, box 66.

72. Board of directors, meeting no. 41 (special meeting), 26 January 1928, Ammonia Corporation, box 66.

73. Niagara Ammonia Bankrupt. Ammonia Corporation Creditor, also is Insolvent, New York Times, 16 February 1928, p. 37.

74. Denham, Sentimental History, p. 144.

75. Independently, Air Liquide eventually modified its Claude process, with, in the case of the Mississippi Chemical Corporation of Yazoo City, Missouri, two converters in series, and recirculation of unreacted gases. H. L. Thompson, P. Guillaumeron, N. C. Updegraff, Ammonia Synthesis at 1000 Atmospheres: The Present-day Claude Process, Chem. Eng. Prog., 1952, 48(9), 468-476. See also W. H. Shearon, H. L. Thompson, Ammonia at 1000 Atmospheres, p. 260

76. B. Waeser, Die Luftstickstoff-Industrie (1932), pp. 163164; C. Stewart, A Glance at 25 Years. In Denham, Sentimental History, pp. 16-18 (from an account written in May 1950).

77. Denham, Sentimental History.

78. R. Norris Shreve, The Chemical Process Industries. McGraw-Hill Book Company, New York, 1945, pp. 402-404.
79. The Pressure Synthesis of the Du Pont Ammonia Corp., Ind. Eng. Chem., 1930, 22(5), 433-437, on 433.

80. Jasper E. Crane, of Du Pont, to George W. Norris, senator, Nebraska, 8 May 1933, in H. Tongue, The Design and Construction of High Pressure Chemical Plant. Chapman \& Hall, London, 1934, pp. 377-378.

81. G. W. Taylor, Nitrogen Production Facilities in Relation to Present and Future Demand. In Agronomy: A Series of Monographs. Vol III. Fertilizer Technology and Resources in the United States (Ed.: K. D. Jakob) Academic Press, New York, 1953, pp. 15-61, on 43.

82. Du Pont Ammonia Corp. Dissolved, Chem. Eng. News, 1931, 9(17), 28.

83. Hounshell and Smith, Science and Corporate Strategy, pp. 186-189.

84. P. H. Spitz, Petrochemicals: The Rise of an Industry. John Wiley \& Sons, New York, 1988, pp. 274-279.

85. S. B. McGrayne, Prometheans in the Lab: Chemistry and the Making of the Modern World. McGraw-Hill, New York, 2001, pp. 79-105, esp. 96-101.

86. Sales of anhydrous ammonia were made to the distributors Pacific Ammonia \& Chemical, the main purchaser, and National Ammonia Co., Inc.; and of liquor to Hercules California, Du Pont Washington, and Fleischmann, of Sumner, Washington, totalling 276,633 pounds of ammonia. Walter Dannenbaum, vice president, to board of directors, Pacific Nitrogen Corporation, 13 July 1928. Pacific Nitrogen Corporation. Reports of Walter Dannenbaum 1926-29. Hagley, Accession 500, box 1471.

87. Pacific Nitrogen Corporation. Board of Trustees, minutes of special meeting, 24 April 1928. Present: F. A. Wardenburg, in the chair; Jasper E. Crane; Walter Dannenbaum, vice president; H. Dannenbaum; Walter U. Reisinger, treasurer. Pacific Nitrogen Corporation, Minutes, 1924-31. Stockholders and Board of Trustees. Hagley, Accession 500, box 1468 (hereafter Pacific Nitrogen).

88. Pacific Nitrogen Corporation. Board of Trustees. Minutes of special meeting, 31 December 1930, Pacific Nitrogen.

89. Haynes, The Merger Era, p. 88.

90. Ernst, Fixation of Atmospheric Nitrogen, p. 94; Haynes, The Chemical Companies, p. 213.

91. Significant Trends in Nitrogen Fixation, Ind. Eng. Chem., 1927, 19(12), 1307.

92. A. D. Chandler, Jr., T. Hikino, D. Mowery, The Evolution of Corporate Capability and Corporate Strategy and Structure Within the World's Largest Chemical Firms: The Twentieth Century in Perspective. In Chemicals and Long-Term Economic Growth: Insights 
from the Chemical Industry (Eds.: A. Arora, R. Landau, N. Rosenberg) John Wiley \& Sons, New York, 1998, pp. 415-457, 417-421.

93. A. S. Travis, Dyes Made in America, 1915-1980. The Calco Chemical Company, American Cyanamid and the Raritan River. Sidney M. Edelstein Center/Hexagon Press, Jerusalem, 2004. 